\title{
A New Direction for US Climate Policy:
}

\author{
Assessing the First 100 Days of Donald Trump's Presidency
}

Michael Mehling*

Following his surprise election, President Trump has translated several campaign promises into a relentless progression of executive measures. This article traces the first 100 days of his presidency as they relate to climate and energy policy, assessing the impact of personnel choices, his regulatory reform agenda, and his proposed budget blueprint, as well as executive or agency orders across various sectors. It also differentiates between the expected impact of federal policy choices and fundamental trends in the energy sector as well as the activist role of states and municipalities in shaping climate policy outcomes. Finally, the article discusses procedural constraints and judicial review as moderating forces, limiting the scale and speed with which the new president can overturn the climate legacy of his predecessor. In the end, the article argues that a retrospective of recent administrations reveals a cyclical pattern which both confines and perpetuates the alternating extremes of successive presidencies.

\section{Background}

On 20 January 2017, Donald J Trump ascended to the highest office in the United States (US), the presidency. His surprising victory in the Electoral College - which portends a major ideological shift in American energy and environmental policy - has been

* Michael Mehling, Deputy Director, Center for Energy and Environmental Policy Research (CEEPR), Massachusetts Institute of Technology (MIT), Cambridge, Mass; Professor of Practice, School of Law, University of Strathclyde, Glasgow. For correspondence: $<$ mmehling@mit.edu>.

DOI:10.21552/cclr/2017/1/4

1 On 6 November 2012, Donald J Trump famously tweeted: 'The concept of global warming was created by and for the Chinese in order to make U.S. manufacturing non-competitive', followed by several tweets in 2013 and 2014 describing climate change as a 'hoax'; on 2 January 2014, he reacted to cold weather by tweeting: 'This very expensive GLOBAL WARMING bullshit has got to stop.'

2 See, for instance, a letter addressed to President Barack Obama and the US Congress printed in the New York Times (6 December 2009) calling for a global climate deal at COP 15 , signed by Donald Trump and three of his children: 'We support your effort to ensure meaningful and effective measures to control climate change, an immediate challenge facing the United States and the world today.' met with significant concern in the environmental community both domestically and abroad. During an acrimonious and controversial election season, he repeatedly vowed to overturn the climate legacy of his predecessor, Barack H Obama, citing doubts about the very existence of climate change ${ }^{1}$ and arguing that related policy measures were harming the US economy and destroying jobs. Still, given that he had at one point expressed support for robust climate action, ${ }^{2}$ it initially remained unclear to what extent the conflicting remarks Trump made during the campaign would also shape his executive decisions once he assumed office. As the first 100 days of his presidency come to a close, however, a number of early policy steps provide a growing body of evidence for the policy vision of the new administration - and this vision is remarkably aligned with candidate Trump's campaign rhetoric in recent years.

Many of the central pillars of this vision can be traced back to a campaign speech the candidate held before a an annual petroleum conference in Bismarck, North Dakota, on 26 May 2016. On this occasion, he outlined the contours of his 'America First Energy Plan', which included immediate steps to rescind 
executive actions on climate change, lift restrictions on fossil fuel extraction, 'cancel the Paris Climate Agreement and stop all payments of US tax dollars to U.N. global warming programs. ${ }^{3}$ Likewise, his appointments to lead the transition at key government agencies suggested an uncompromising hostility towards environmental safeguards, and to climate policy in particular. ${ }^{4}$ Fears that President Trump would undo years of progress on climate policy received further impetus when he announced his designated cabinet, with a number of prospective members who have long ties to the fossil fuel industry or a track record of opposing government action on climate change. In the meantime, the cabinet has been confirmed, including the following heads of federal departments and agencies with responsibility for climate policy:

- E Scott Pruitt, the former Attorney General for Oklahoma, as Administrator of the Environmental Protection Agency (EPA). During the presidency of Barack Obama, Pruitt sued the EPA in over a dozen cases, repeatedly questioning the scientific threat and seriousness of climate change and the need for federal climate action. ${ }^{5}$ Extensive correspondence released after a court order revealed close coordination of his office with major oil, gas and coal producers, electric utilities and other in- dustry groups. ${ }^{6}$ Since his appointment, Pruitt has indicated his intention to promote an agenda of 'originalism' at the EPA, reversing 'regulatory assault' on industry and devolving authority to the states. $^{7}$

- J Richard Perry, former Governor of Texas, as Secretary of Energy. Perry dismissed climate change and alleged a 'cooling trend' in a 2010 book, ${ }^{8}$ and once promised to eliminate - but then failed to remember the name of - the Department of Energy (DOE) during a Republican primary debate on 9 November 2011.

- Rex W Tillerson, former Chairman and CEO of ExxonMobil Corp, as Secretary of State. While Tillerson himself has affirmed the scientific consensus on climate change and endorsed policy action, the company he formerly led is under investigation for potentially misleading consumers and investors about the risks of climate change. $^{9}$

- Ryan Zinke, former Navy SEAL and a Member of the US House of Representatives for Montana, as Secretary of the Interior, heading a department with oversight over the use of federal lands, including oil, gas and coal extraction. Zinke has wavered in his affirmation of climate change and support for climate action. ${ }^{10}$
3 Donald J Trump, 'An America First Energy Plan' (26 May 2016) $<$ http://www.donaldjtrump.com/press-releases/an-america-first -energy-plan> accessed 29 March 2017. Most of these pledges are contained in a version uploaded to the website of the White House, 'An America First Energy Plan' <https://www.whitehouse .gov/america-first-energy> accessed 29 March 2017.

4 Myron Ebell, who led the transition at the Environmental Protec tion Agency (EPA), is the Director of Energy and Environment at the Competitive Enterprise Institute (CEI). He is openly a climateskeptic, and helped co-author the chapter on energy and environment in Ivan Osorio and Gregory Conko (eds), Free to Prosper: A Pro-Growth Agenda for the $115^{\text {th }}$ Congress (CEI 2016), which sets out ten recommendations to dismantle US domestic and foreign climate policy. Many of these recommendations were also picked up by Thomas Pyle, President of the influential Institute for Energy Research (IER) and its advocacy arm, the American Energy Alliance (AEA), who led the transition at the Department of Energy (DOE) and indicated his policy preferences in a letter to stakeholders on 15 November 2016, see Nick Surgey, 'Revealed: The Trump Administration's Energy Plan' (Center for Media and Democracy, 4 December 2016) <http://www.exposedbycmd.org/ 2016/12/04/revealed-trump-energy-plan> accessed 29 March 2017.

5 See eg E Scott Pruitt and Luther Strange, 'The Climate-Change Gang' (National Review, 17 May 2016) <http://www .nationalreview.com/article/435470/climate-change-attorneys -general-overstep-their-authority> accessed 29 March 2017. Pruitt has since been under criticism for suggesting that carbon dioxide $\left(\mathrm{CO}_{2}\right)$ is not 'a primary contributor to the global warming that we see', see Tom DiChristopher, 'EPA Chief Scott Pruitt Says Carbon Dioxide Is Not a Primary Contributor to Global Warming' (CNBC, 9 March 2017) <http://www.cnbc.com/2017/03/09/epa-chief -scott-pruitt.html> accessed 29 March 2017.

6 Coral Davenport and Eric Lipton, 'E.P.A. Chief Was Cozy With Energy Industry, Trove of Emails Shows' (New York Times, 23 February 2017) A13.

7 Charlie Spiering, 'Exclusive: Scott Pruitt Promises 'EPA Originalism' in Donald Trump Administration' (Breitbart, 28 March 2017) $<$ http://www.breitbart.com/big-government/2017/03/28/exclusive -scott-pruitt-promises-epa-orginalism-in-donald-trump -administration> accessed 29 March 2017.

8 Rick Perry, Fed Up! Our Fight to Save America from Washington (Little, Brown \& Co 2010) 92.

9 A coalition of State Attorneys General, led by Eric T Schneiderman of New York and Maura T Healey of Massachusetts, have formally issued subpoenas and civil investigative demands to ExxonMobil, see, for instance, Commonwealth of Massachusetts, Office of the Attorney General, 'Civil Investigative Demand' (19 April 2016) <http://www.mass.gov/ago/docs/energy-utilities/ exxon/ma-exxon-cid-.pdf> accessed 29 March 2017.

10 Chelsea Harvey, 'Trump's Pick for Interior Secretary Can't Seem to Make Up His Mind About Climate Change' (Washington Post, 21 December 2016) <http://www.washingtonpost.com/news/energy -environment/wp/2016/12/21/trumps-pick-for-interior-secretary -cant-seem-to-make-up-his-mind-about-climate-change $>$ accessed 29 March 2017. 
- Elaine L Chao as Secretary of Transportation, with partial responsibility for addressing environmental impacts from the transport sector. Chao was previously a Distinguished Fellow with the conservative Heritage Foundation, where she drafted a commentary opposing efforts by the $111^{\text {th }}$ Congress to address climate change. ${ }^{11}$

- Jefferson B Sessions, a Senator from Alabama, as Attorney General, an important role in any legal proceedings against regulatory measures of the current administration, or in enforcing measures adopted under the previous administration. Sessions has consistently opposed action against climate change, repeatedly questioning its existence and the risks posed by carbon dioxide. $^{12}$

Other members of the cabinet, such as the Secretary of Health and Human Services Thomas E Price, ${ }^{13}$ or the nominee for Secretary of Agriculture George E 'Sonny' Perdue, ${ }^{14}$ have also openly questioned the science of climate change and opposed any related policy action. An unusual number of lower level appointments have remained vacant two months after the inauguration, ${ }^{15}$ impeding the ability of many agencies to work effectively; yet where positions have been filled, the foregoing pattern of hostility against climate action is perpetuated, for instance at the EPA, where several senior positions have been filled with candidates who expressly question or deny the scientific consensus on climate change. $^{16}$

11 Elaine Chao, 'A Return to Prosperity is Light-Years Away if We Follow Obama's Road Map' (4 September 2009) <http://www .heritage.org/budget-and-spending/commentary/return-prosperity -light-years-away-if-we-follow-obamas-road-map> accessed 29 March 2017.

12 In a Senate hearing with former EPA Administrator Regina McCarthy, Sessions implied that '[c]arbon pollution is $\mathrm{CO}_{2}$, and that's really not a pollutant; that's a plant food, and it doesn't harm anybody', see US Senate, Committee on Environment \& Public Works (EPW), 'Environment Oversight Hearing: Examining the President's Budget Request for the U.S. Environmental Protection Agency' 50-1 (4 March 2015) <http://www.epw.senate.gov/ public/_cache/files/1dc249c2-7677-47f6-b33a-5c241105fa7e/ spw030415.pdf> accessed 29 March 2017.

13 Price, previously a Representative for Georgia, signed a pledge to oppose carbon pricing ('No Climate Tax Pledge') spearheaded by Americans for Prosperity, see 'Pledge Takers' <http:// noclimatetax.com/pledge-takers> accessed 29 March 2017; he also supported legislation to curb EPA carbon emission constraints by claiming 'many revelations of errors and obfuscation in the allegedly "settled science" of global warming', see 'Repub-
Less than 100 days into the new presidency, the White House has already mandated a review or rescission of several federal climate policies. Few of these orders have immediate effect, however, requiring observance of lengthy administrative procedures which, in turn, will be vulnerable to litigation by states and environmental advocacy groups. It also remains unclear whether executive action can halt or reverse dynamics that are primarily driven by state and local policies and market fundamentals. Whether or not President Trump can, thus, use a reversal of climate policy progress under his predecessor to advance his declared objective of deconstructing the 'administrative state', as his Chief Strategist Stephen K Bannon has framed it, ${ }^{17}$ remains to be seen. All the main actions taken by the administration since the inauguration are described in the following section, and the impacts they are likely to have are then discussed in a concluding section.

\section{Actions by the Administration and $115^{\text {th }}$ Congress}

\section{Regulatory Reform}

An early harbinger of the regulatory reform agenda of the new administration was promptly unveiled on inauguration day, when the White House Chief of Staff Reinhold R Priebus issued a memorandum to all agencies ordering a regulatory freeze and requir-

licans Continue to Fight National Energy Tax' (2 March 2010) $<$ http://votesmart.org/public-statement/490191/republicans -continue-to-fight-national-energy-tax> accessed 29 March 2017.

14 Perdue, the former Governor of Georgia, wrote a commentary in the National Review challenging any connection between climate change and extreme weather events, and calling climate change 'a running joke among the public': Sonny Perdue, 'The Common Core Blame Game' (National Review, 8 May 2014) <http://www .nationalreview.com/article/377495/common-core-blame-game -sonny-perdue> accessed 29 March 2017.

15 Partnership for Public Service, 'Political Appointee Tracker' (2017) < http://ourpublicservice.org/issues/presidential -transition/political-appointee-tracker.php> accessed 29 March 2017.

16 Coral Davenport, 'New Administrator Stacks E.P.A. With Climate Change Skeptics' (New York Times, 8 March 2017) A17.

17 Philip Rucker and Robert Costa, 'Bannon Presses "Deconstruction"' Washington Post (24 February 2017), A1. 
ing all new or pending regulations - broadly defined to include any regulatory action or guidance documents that set forth 'a policy on a statutory, regulatory, or technical issue or an interpretation' thereof - to obtain approval from a political appointee of the new administration. ${ }^{18}$ Among the rules affected by this memorandum are a number of energy efficiency and renewable fuel standards, along with several dozen other rules issued by the EPA and DOE during the last months of the previous administration. ${ }^{19}$ President Trump soon after signed an Executive Order requiring federal agencies to repeal at least two existing regulations for every newly issued regulation, and to do so in a way that ensures the total cost of regulations does not increase. ${ }^{20} \mathrm{~A}$ subsequent Executive Order ensures observance of this agenda by establishing a Regulatory Reform Officer and Task Force in each agency. ${ }^{21}$ Although these orders raise many questions and their legality is already being disputed ${ }^{22}$ they signal a strong commitment of the new administration to unraveling the framework of executive rules and interpretations iterated over the years by previous administrations.

\section{Federal Budget}

In March, two months into the presidency of Donald Trump, the White House released its budget blue-

18 White House, Office of the Press Secretary, 'Memorandum for the Heads of Executive Departments and Agencies' (20 January 2017) $<$ https://www.whitehouse.gov/the-press-office/2017/01/20/ memorandum-heads-executive-departments-and-agencies $>$ accessed 29 March 2017.

19 See, for instance, the list compiled by the EPA, 'Delay of Effective Date for 30 Final Regulations Published by the Environmental Protection Agency Between October 28, 2016 and January 17, $2017^{\prime}$ of 26 January 2017 (2017) 82 (16) Federal Register 8499.

20 Executive Order 13771, 'Reducing Regulation and Controlling Regulatory Costs' of 30 January 2017 (2017) 82(22) Federal Register 9339.

21 Executive Order 13777, 'Enforcing the Regulatory Reform Agenda' of 24 February 2017 (2017) 82(39) Federal Register 12285

22 Arguing that this order would prevent agencies from complying with statutory requirements, Michael Burger and Jessica Wentz, 'Trump's Executive Order On Regulatory Costs Undermines Congressional Authority' (Huffington Post, 16 February 2017) $<$ http://www.huffingtonpost.com/entry/trumps-executive-order -on-regulatory-costs-undermines-congressional-authority_us 58a61a0de4b037d17d26215c> accessed 29 March 2017. See generally Marcus Peacock, 'Implementing a Two-for-One Regulatory Requirement in the U.S.' (George Washington Univer- print for $2018 .{ }^{23}$ With an emphasis on national security and public safety, the budget blueprint proposes significant increases in defense spending, homeland security and law enforcement as 'a message of American strength, security, and resolve. ${ }^{24}$ Extensive cutbacks to unrelated agencies and programmes would maintain budget neutrality and avoid increasing national debt. Among the agencies hit hardest by proposed expenditure cuts are the three agencies with substantial responsibilities for climate change: the EPA, the DOE and the Department of State. Specifically, the blueprint proposes the following budgetary changes:

- Under the budget blueprint, the EPA would see its 2018 budget shrink by $31.4 \%$ to $\$ 5.7$ billion, ${ }^{25}$ the largest cut in relative terms to any federal agency, and a significantly larger cut than requested by Congressional Republicans. ${ }^{26}$ In particular, the blueprint discontinues 'funding for the Clean Power Plan, international climate change programs, climate change research and partnership programs, and related efforts,' consistent with the 'America First Energy Plan' pledged during the campaign and the 'priority to ease the burden of unnecessary Federal regulations' expressed in the budget itself. ${ }^{27}$ Among the envisioned cuts are 224 staff and 14 voluntary programmes under the Climate Protection Programme, including the popular 'Energy Star' la-

sity Regulatory Studies Center, 7 December 2016) <http:// regulatorystudies.columbian.gwu.edu/sites/regulatorystudies .columbian.gwu.edu/files/downloads/Peacock_Implementing -Two-For-One\%2012-2016_final.pdf> accessed on 29 March 2017. On 8 February 2017, three advocacy groups filed a complaint for declaratory and injunctive relief against Executive Order 13771, alleging multiple violations of statutory law: Public Citizen Inc. et al v Donald Trump et al, US District Court for the District of Columbia, Case 1:17-cv-00253 [8 February 2017].

23 Executive Office of the United States, Office of Management and Budget, 'America First: A Budget Blueprint to Make America Great Again' (16 March 2017) <https://www.whitehouse.gov/ sites/whitehouse.gov/files/omb/budget/fy2018/2018_blueprint.pdf $>$ accessed 29 March 2017

24 ibid 1.

25 ibid 41

26 See the critical assessment by former EPA Administrator Christine Todd Whitman, 'I Ran George W. Bush's EPA—and Trump's Cuts to the Agency Would Endanger Lives' (The Atlantic, 31 March 2017) <http://www.theatlantic.com/politics/archive/ 2017/03/trumps-epa-cuts-budget/521223> accessed 31 March 2017.

27 Executive Office (n 23) 41. 
beling standard for energy efficient consumer products, which would be completely eliminated. $^{28}$

- For the DOE, the budget blueprint requests $\$ 28.0$ billion, a $5.6 \%$ decrease. Because this includes a substantial budget increase for the National $\mathrm{Nu}$ clear Security Administration, however, all remaining programmes - including the Office of Energy Efficiency and Renewable Energy (EERE), or the Advanced Research Projects Agency-Energy (ARPA-E) - will effectively see an aggregate $17.9 \%$ decrease in funding. Additionally, the budget blueprint announces 'an increased reliance on the private sector to fund later-stage research, development, and commercialization of energy technologies. ${ }^{29}$

- Extensive cuts are also requested for the Department of State and associated international programmes, ${ }^{30}$ which together would see their budget reduced by $28 \%$ to $\$ 25.6$ billion. Citing the need to achieve an 'appropriate U.S. share of international spending' and 'reduce or end direct funding for international organizations whose missions do not substantially advance U.S. foreign policy interests', the budget proposes to eliminate 'the Global Climate Change Initiative and ... cease payments to the United Nations' (UN) climate change programs. ${ }^{31}$ Likewise, it anticipates cuts to US funding for multilateral development

28 See David A Bloom, Acting Chief Financial Officer, EPA, 'Memorandum: FY 2018 President's Budget: Major Policy and Final Resource Decisions' (21 March 2017), on file with author.

29 Executive Office (n 23) 19

30 These include the US Agency for International Development (USAID) and the International Programmes at the Department of the Treasury, ibid 33

31 Specifically, the budget blueprint eliminates all US funding related to the Green Climate Fund and precursor climate investment funds, see Executive Office (n 23) 33

32 ibid 33.

33 ibid 13.

34 ibid 35.

35 ibid 27.

36 George Cahlink, 'White House Outlines More Cuts for Energy, Environment' (E\&E News, 28 March 2017) <http://www.eenews .net/greenwire/stories/1060052208> accessed 29 March 2017.

37 Executive Office (n 23) 5.

38 Energy Information Administration (EIA), 'Monthly Energy Review March 2017' 184-5 (28 March 2017) <https://www.eia.gov/ totalenergy/data/monthly/archive/00351703.pdf> accessed 29 March 2017. banks, including the World Bank, by approximately $\$ 650$ million over three years compared to commitments made by the previous administration. $^{32}$

- Other relevant areas threatened with dramatic spending cuts are the National Oceanic and Atmospheric Administration (NOAA) at the Department of Commerce ${ }^{33}$ and subsidies for long distance train services through the Department of Transportation (DOT), ${ }^{34}$ while the Department of the Interior (DOI) would see an increase in funding for programmes that support development of energy on public lands and offshore waters. $^{35}$

In addition to the foregoing cuts for 2018, the White House has requested Congress to reduce spending for energy and environmental programs for the current fiscal year, after the Continuing Resolution that is currently preventing a government shutdown expires. Proposed on 24 March 2017, these requests include steep cuts of more than $\$ 650$ million to the budgets of ARPA-E and EERE at the DOE, which would effectively eliminate a number of grants and rescind unobligated spending for commercialisation of clean energy technologies. ${ }^{36} \mathrm{Im}$ portantly, these proposals and the budget blueprint are only an indication of the priorities of the administration, outlining discretionary funding proposals; both the requested changes for 2017 and a full budget request for 2018 - expected sometime in May - will have to pass Congress, where they are likely to undergo significant change. Given the magnitude and focus of the spending cutbacks, however, they leave little doubt about the administration's expressed objective of 'focusing funding to redefine the proper role of the Federal Government. ${ }^{37}$

\section{Transportation Sector}

In 2016, after years of falling greenhouse gas (GHG) emissions from electricity generation, the transportation sector became the single largest source of emissions in the US. ${ }^{38}$ It also became the first target of executive climate action during the administration of President Obama, when the EPA and the National Highway Traffic Safety Administration (NHTSA) drew on rulemaking authorities under the 
Energy Policy and Conservation Act (EPCA) ${ }^{39}$ and the Clean Air Act ${ }^{40}$ to issue joint Corporate Average Fuel Economy (CAFE) and GHG emissions standards for passenger cars and light trucks manufactured between 2012 and 2016. ${ }^{41}$ A second phase would require passenger cars and light trucks manufactured between 2017 and 2025 to achieve a fleet average of 54.5 miles per gallon by $2025,{ }^{42}$ contributing to a projected reduction of tailpipe GHG emissions by 2 billion metric tons over the lifetime of vehicles sold during that period. ${ }^{43}$ Less than two months after the inauguration of President Trump, on 15 March 2017, the new administration announced that it would reinstate a midterm evaluation of the standards, ${ }^{44}$ signaling its intention to review whether these are excessively burdensome relative to the GHG emissions reductions and fuel savings they would achieve. ${ }^{45}$ The outgoing administration had cut short the midterm evaluation process just days before the transition with a determination concluding that no changes to the second phase covering model years 2017 to 2025 were warranted. ${ }^{46}$ A new determination is expected by 1 April 2018, and observers predict

39 94 $4^{\text {th }}$ Congress, S622 (22 December 1975), Pub. L. 94-163, 89 Stat. 871 , as amended by the Energy Independence and Security Act (EISA), $110^{\text {th }}$ Congress, HR 6 (19 December 2007), 42 US Code Chapter $152 \S 17001$.

$4088^{\text {th }}$ Congress, HR 6518, 'An Act to Improve, Strengthen, and Accelerate Programs for the Prevention and Abatement of Air Pollution (Clean Air Act)' (17 December 1963), as amended in 1967, 1970 and 1990, 42 US Code Chapter 85 § 7401. In 2007, the US Supreme Court had determined in Massachusetts $v$ Environmental Protection Agency et al [2 April 2007] 549 US 497 (2007) that the EPA shall regulate GHG emissions if it concludes that, by causing or contributing to climate change, these GHGs endanger both public health and the public welfare of current and future generations. Late in 2009, the EPA issued such a finding, see 'Endangerment and Cause or Contribute Findings for Greenhouse Gases under the Section 202(a) of the Clean Air Act', of 7 December 2009, 40 CFR Chapter I (2009) 74(239) Federal Register 66496.

41 In this first phase, new vehicles sold in 2016 are mandated to achieve an average fuel efficiency of 35.5 miles per gallon by 2016, based on a CAFE standard of 34.1 miles per gallon and a GHG emissions limit of 250 grams per mile, see DOT NHTSA and EPA, 'Light-Duty Vehicle Greenhouse Gas Emission Standards and Corporate Average Fuel Economy Standards; Final Rule' of 1 April 2010, 40 CFR Parts 85, 86, and 600 (2010) 75(88) Federal Register 25324. These standards are projected to save 61.0 billion gallons of fuel and reduce GHG emissions by 654.7 million metric tons over the lifetimes of the sold vehicles, see National Highway Traffic Safety Administration, 'Fact Sheet: NHTSA and EPA Establish New National Program to Improve Fuel Economy and Reduce Greenhouse Gas Emissions for Passenger Cars and Light Trucks' (no date given) $5<$ https://www.nhtsa.gov/sites/nhtsa .dot.gov/files/cafe-ghg_fact_sheet.pdf> accessed 29 March 2017.

42 Equaling an average industry level of approximately 163 grams/mile of $\mathrm{CO}_{2}$ in model year 2025, see DOT NHTSA and EPA, 'Greenhouse Gas Emissions and Fuel Efficiency Standards for Medium- and Heavy-Duty Engines and Vehicles: Phase 2; that the standards will be 'substantially relaxed' in view of a changing vehicle fleet following a period of low gasoline prices. ${ }^{47}$ All standards were at one point agreed with vehicle manufacturers during earlier stakeholder consultations, but have come under increasing pressure with fears of growing compliance costs. It remains unclear whether similar standards for medium and heavy duty vehicles produced between 2018 and 2029 will also be reviewed. ${ }^{48}$ Likewise, there is no indication as yet that the EPA would rescind a waiver issued under Section 209 of the Clean Air Act, allowing California - and, pursuant to Section 177, any other states willing to follow the Californian lead - to adopt stricter standards within their territory; because vehicle manufacturers tend to uniformly adhere to the more ambitious Californian standards rather than design different vehicle models for uneven environmental standards across the United States, a weakening of federal tailpipe emission standards may have limited effect only, unless the EPA moves to reverse a previously granted waiver or Congress amends its legal basis in the Clean Air Act.

Final Rule' of 16 August 2016, 40 CFR Parts 9, 22, 85, 86, 600 , 1033, 1036, 1037, 1039, 1042, 1043, 1065, 1066, and 1068, 49 CFR Parts 523, 534, 535, and 538 (2016) 81(206) Federal Register 73478.

43 EPA Office of Transportation and Air Quality, 'Regulatory Announcement EPA-420-F-12-05' (1 August 2012) <https://nepis.epa .gov/Exe/ZyPDF.cgi/P100EZ7C.PDF?Dockey=P100EZ7C.PDF> accessed 29 March 2017

44 Department of Transportation (DOT) and EPA, Notice of Intention To Reconsider the Final Determination of the Mid-Term Evaluation of Greenhouse Gas Emissions Standards for Model Year 2022-2025 Light Duty Vehicles' of 3 March 2017 (2017) 82(54) Federal Register 14671.

45 White House, Office of the Press Secretary, Press Release of 15 March 2017 <https://www.whitehouse.gov/the-press-office/2017/ 03/15/president-donald-j-trump-buy-american-and-hire-american -united-states> accessed 29 March 2017.

46 EPA, 'Final Determination on the Appropriateness of the Model Year 2022-2025 Light-Duty Vehicle Greenhouse Gas Emissions Standards under the Midterm Evaluation' (12 January 2017) <https://www.epa.gov/sites/production/files/2017-01/documents/ 420r17001.pdf> accessed 29 March 2017.

47 Jason P Britt, 'President Trump Orders EPA Review of Corporate Average Fuel Economy Standards' (Dashboard Insights, 20 March 2017) < https://www.autoindustrylawblog.com/2017/03/20/ president-trump-orders-epa-review-of-corporate-average-fuel -economy-standards> accessed 29 March 2017.

48 DOT NHTSA and EPA, 'Greenhouse Gas Emissions and Fuel Efficiency Standards for Medium- and Heavy-Duty Engines and Vehicles: Phase 2' of 16 August 2016, 40 CFR Parts 9, 22, 85, 86, $600,1033,1036,1037,1039,1042,1043,1065,1066$, and 1068, 49 CFR Parts 523, 534, 535, and 538 (2016) 81(206) Federal Register 73478 . The agencies estimate that these standards will save up to 2 billion barrels of oil and reduce $\mathrm{CO}_{2}$ emissions by up to 1.1 billion metric tons over the lifetimes of new vehicles sold between 2018 and 2029. 


\section{Energy Sector}

Several measures adopted at the outset of the new administration share one central objective: to reduce the regulatory burden on oil, gas and coal production. Collectively, they recalibrate the balance of environmental and economic interests in the energy sector, as repeatedly pledged during the election campaign. Already in February, the Interior Department suspend$\mathrm{ed}^{49}$ and then, in April, formally proposed repealing ${ }^{50}$ a revised accounting system to govern how oil and gas produced from federal leases is valued. ${ }^{51}$ Reforming the valuation methodology was expected to increase royalty payments by ensuring that revenue collection for federal mineral resources is based on fair market value. $^{52}$ President Trump took another step towards regulatory reform in March, when he signed an Executive Order directing the EPA and the US Army Corps of Engineers (ACE) to revisit a federal rule ${ }^{53}$ that defines the phrase 'Waters of the United States' (WOTUS) in the Clean Water Act (CWA). ${ }^{54}$ By narrowing the scope of federal safeguards for surface waters, this review will primarily benefit the agricultural sector, but will also lessen the permitting and compliance requirements for coal mining and oil and gas production. Finally, less than a month after inauguration, Congress exercised a provision under the Congressional

49 Department of the Interior, Office of Natural Resources Revenue, 'Postponement of Effectiveness of the Consolidated Federal Oil \& Gas and Federal \& Indian Coal Valuation Reform 2017 Valuation Rule' of 22 February 2017, 30 CFR Parts 1202 and 1206 (2017) 82(37) Federal Register 11823.

50 Department of the Interior, Office of Natural Resources Revenue, 'Repeal of Consolidated Federal Oil \& Gas and Federal \& Indian Coal Valuation Reform' of 4 April 2017, 30 CFR Parts 1202 and 1206 (2017) 82(63) Federal Register 16323.

51 Department of the Interior, Office of Natural Resources Revenue, 'Consolidated Federal Oil \& Gas and Federal \& Indian Coal Valuation Reform' of 1 July 2016, 30 CFR Parts 1202 and 1206 (2016) 81(127) Federal Register 43338.

52 This change in value accounting would have prevented artificially low royalty payments through a leaseholder practice of initially selling mined products to affiliated companies at prices below fair market value before selling on international markets.

53 ACE and EPA, 'Clean Water Rule: Definition of "Waters of the United States"' of 29 June 2015 (2015) 80(124) Federal Register 37054.

54 Executive Order 13778, 'Restoring the Rule of Law, Federalism, and Economic Growth by Reviewing the "Waters of the United States" Rule' of 28 February 2017 (2017), 82(41) Federal Register 12497

$55104^{\text {th }}$ Congress, HR 3136, 'Contract with America Advancement Act of 1996' (28 March 1996) Pub L 104-121, Sec 251: Congressional Review of Agency Rulemaking, US Code Title 5 Part I Chapter 8.
Review Act (CRA) ${ }^{55}$ for the expedited reversal of a rule protecting surface water, groundwater, fish, wildlife and other natural resources from surface coal mining debris, the 'Stream Protection Rule.' ${ }^{56}$ This rule had been issued during the last weeks of the previous administration $^{57}$ to clarify a statutory obligation requiring mining companies to avoid 'material damage to the extent technologically and economically feasible. ${ }^{58}$

On infrastructure, the new administration approved two controversial projects, the Keystone XL and the Dakota Access pipelines, after ordering an expedited authorisation process within days of the inauguration. ${ }^{59}$ An easement from the ACE enabled construction of the Dakota Access Pipeline, which connects oil producers in the North Dakota Bakken and Three Forks areas to an oil terminal hub in Illinois. ${ }^{60}$ A decision by the Secretary of the Army to proceed without an environmental impact statement under the National Environmental Policy Act (NEPA), as previously intended, ${ }^{61}$ allowed the easement to be granted already on 8 February 2017. On 24 March 2017, construction and operation of Keystone XL, a pipeline designed to transport synthetic crude oil and diluted bitumen from Canadian oil sand facilities through the US Midwest to ports in the Gulf of Mexico, was approved with a Presidential Permit issued by the Department of State. ${ }^{62}$ Unlike the ear-

56 Department of the Interior, Office of Surface Mining Reclamation and Enforcement (OSMRE), 'Stream Protection Rule' (20 December 2016) 81(244) Federal Register 93066.

$57115^{\text {th }}$ Congress HJRes38, 'Joint Resolution Disapproving the Rule Submitted by the Department of the Interior Known as the Stream Protection Rule' (16 February 2017), Public Law 115-5.

58 Surface Mining Control and Reclamation Act (SMCRA) (3 August 1977) 30 USC §§ 1201-1328, § 1266(b)(1).

59 White House, 'Presidential Memorandum Regarding Construction of the Dakota Access Pipeline' (24 January 2017) <https://www .whitehouse.gov/the-press-office/2017/01/24/presidential -memorandum-regarding-construction-dakota-access-pipeline> accessed 29 March 2017; White House, 'Presidential Memorandum Regarding Construction of the Keystone XL Pipeline' (24 January 2017) <https://www.whitehouse.gov/the-press-office/ 2017/01/24/presidential-memorandum-regarding-construction -keystone-xl-pipeline> accessed 29 March 2017.

60 ACE, 'Corps Grants Easement to Dakota Access, LLC' (8 February 2017 ) <http://www.nwo.usace.army.mil/Media/News-Releases/ Article/1077134/corps-grants-easement-to-dakota-access-Ilc $>$ accessed 29 March 2017.

61 Department of Defense, Department of the Army, Notice of Intent to Prepare an Environmental Impact Statement in Connection With Dakota Access, LLC's Request for an Easement To Cross Lake Oahe, North Dakota' of 17 January 2017 (2017) 82(11) Federal Register 5543.

62 Department of State, 'Issuance of Presidential Permit to TransCanada for Keystone XL Pipeline' (24 March 2017) <https://www.state .gov/r/pa/prs/ps/2017/03/269074.htm> accessed 29 March 2017. 
lier pipeline approval, this decision builds on extensive environmental reviews, yet both pipeline projects remain highly politicised due to their potential impacts on water resources and the climate, as well as alleged violations of indigenous and tribal rights. Litigation against the approval decisions is already underway. ${ }^{63}$

Additional directives relevant to the energy sector, affecting restrictions on coal, oil and gas production on federal lands as well as curbs on methane emissions from hydrocarbon activities, were included in a sweeping Executive Order released in late March 2017. Because this Executive Order primarily aims at rolling back a body of rules issued in recent years to address climate change, but also sets out some overarching principles and procedures, the constituent provisions will be discussed in concert in the following section.

\section{Climate Change}

While each of the foregoing actions has ramifications for US energy and environmental policy, an Executive Order signed on 28 March $2017^{64}$ is arguably the single measure most directly aimed at overturning the regulatory legacy on climate change left by the previous administration. Adoption of this order had been repeatedly postponed due to the political setbacks around health care legislation and scrutiny of foreign ties within the administration. ${ }^{65}$ Titled 'Promoting Energy Independence and Economic Growth', the order expressly identifies as its objec- tive 'to promote clean and safe development of ... energy resources' while 'avoiding regulatory burdens that unnecessarily encumber energy production, constrain economic growth, and prevent job creation. ${ }^{66}$ During the signature ceremony, President Trump described its aims in more provocative terms as 'putting an end to the war on coal' and 'ending the theft of American prosperity. ${ }^{167}$ Although it was greeted with approval by parts of the private sector and several states with interests in conventional energy, the Executive Order has also invited heavy criticism from Democrats in Congress as well as the environmental community. Commentators in progressive media outlets have derided it as 'unfortunate and misguided'68 and 'an angry reflex in search of an idea. $^{69}$

In terms of substance, the Executive Order consists of a number of directives to executive departments and agencies aimed at suspending, revising, or rescinding regulations that 'unduly burden the development of domestic energy resources beyond the degree necessary to protect the public interest or otherwise comply with the law. ${ }^{\prime 70}$ It goes on to detail a process requiring agencies to immediately review and identify 'all existing regulations, orders, guidance documents, policies, and any other similar agency actions that potentially burden the development or use of domestically produced energy resources, with particular attention to oil, natural gas, coal, and nuclear energy resources', and solicits each agency to submit within specified timelines a plan for this review as well as, subsequently, a report describing recommended actions. ${ }^{71}$ Additional provi-

63 See, eg, Northern Plains Resource Council et al $v$ Department of State et al, Complaint for Declarative and Injunctive Relief filed with the US District Court for the District of Montana, Great Falls Division [30 March 2017] <http://www.sierraclub.org/sites/www .sierraclub.org/files/blog/Complaint\%20filed\%202017\%2003 \%2030.pdf> accessed 31 March 2017.

64 Executive Order 13783 of 28 March 2017, 'Promoting Energy Independence and Economic Growth' (2017) 82(61) Federal Register 16093.

65 See, eg, Hannah Hess, 'Executive Order Coming Next Week' (Greenwire, 1 March 2017); Robin Bravender, 'Executive Order Coming as Early as Tomorrow' (Greenwire, 6 March 2017); Robin Bravender, 'Trump Order Now "Unlikely" This Week' (Greenwire, 8 March 2017); Robin Bravender, 'Order to Repeal Obama Climate Rule Expected Tomorrow' (E\&E Daily, 13 March 2017); Robin Bravender, 'Waiting Game Continues for Clean Power Plan Order' (Greenwire, 14 March 2017); Kevin Bogardus, 'Pruitt Promises Clean Power Plan Rollback Tomorrow' (E\&E Daily, 27 March 2017).

66 Executive Order 13783 (n 64) s 1(a).

67 White House, 'Remarks by President Trump at Signing of Executive Order to Create Energy Independence' (28 March 2017) <https://www.whitehouse.gov/the-press-office/2017/03/28/ remarks-president-trump-signing-executive-order-create-energy> accessed 30 March 2017

68 Michael J Bloomberg, 'Climate Progress, Without Trump' (New York Times, 31 March 2017) A23.

69 Jonathan Chait, 'Trump's Mindless War on Green Energy' (New York Magazine, 28 March 2017) <http://nymag.com/daily/ intelligencer/2017/03/trumps-mindless-war-on-green-energy.html $>$ accessed 30 March 2017. Chait goes on to describe the order as an 'ultimately doomed effort' by the Republican party 'to ignore a problem with which their dogma cannot grapple.'

70 Executive Order 13783 (n 64) s 1(c).

71 Executive Order 13783 (n 64) s 2. Under that provision, Agencies have 45 days to develop and submit a plan to carry out the review, 120 days to submit a draft report, and 180 days to submit a final report. 
sions throughout the Executive Order direct agency heads to review or withdraw a number of specific actions. Environmental concerns are only mentioned incidentally in all this, with the promotion of 'clean air and clean water' acknowledged as a policy objective, but only 'to the extent permitted by law' and 'while also respecting the proper roles of the Congress and the States concerning these matters. ${ }^{72}$ Ironically, while the political intent of the order is to roll back climate policy measures of the previous administration, the word 'climate' is only mentioned in the context of the regulations and reports to be rescinded.

At the heart of the Executive Order are provisions to reverse the Clean Power Plan, a controversial regulation adopted during the previous administration to limit GHG emissions from existing power plants. ${ }^{73}$ Its importance to former President Obama's regulatory strategy on climate change is reflected in his statement during the announcement ceremony that the Clean Power Plan was 'the single most important step that America has ever made in the fight against global climate change ${ }^{, 74}$ - a statement that stands in stark contrast to President Trump's assessment during the release of his Executive Order that '[p]erhaps no single regulation threatens our miners, energy workers, and companies more than this crushing attack on American industry. ${ }^{, 75}$ Under the Clean Power Plan, GHG emissions from the pow-

72 Executive Order 13783 (n 64) s 1(d).

73 EPA, 'Carbon Pollution Emission Guidelines for Existing Stationary Sources: Electric Utility Generating Units; Final Rule' of 3 August 2015, 40 CFR Part 60 (2015) 80(205) Federal Register 64661.

74 White House, 'Remarks by the President in Announcing the Clean Power Plan' (3 August 2015) <https://obamawhitehouse .archives.gov/the-press-office/2015/08/03/remarks-president -announcing-clean-power-plan> accessed 29 March 2017.

75 White House (n 67).

76 These performance rates, which are broken down by coal- and oil-fired electric steam generating units and natural gas-fired combined cycle generating units, should reflect the 'best system of emissions reduction' (BSER) and be achievable through various 'building blocks', that is, strategies, technologies and measures available to reduce the carbon intensity of electricity generation, such as improving the heat rates in power plants and substituting coal with natural gas or renewable energy technologies.

77 Clean Air Act (n 40) s 111(d)

78 EPA, 'Standards of Performance for Greenhouse Gas Emissions From New, Modified, and Reconstructed Stationary Sources: Electric Utility Generating Units; Final Rule' of 3 August 2015, 40 CFR Parts 60, 70, 71, and 98 (2015) 80(205) Federal Register er sector are mandated to fall $32 \%$ below 2005 levels by 2030, with goals for individual states based on interim and final emissions performance rates for thermal electric generating units. ${ }^{76}$ Years of outreach and public engagement shaped this complex rule, which is entirely based on an authorization to regulate emissions from existing facilities in Section 111(d) of the Clean Air Act. ${ }^{77}$ A separate regulation defining performance standards for new, modified or reconstructed power plants based on Section 111(b) of the Clean Air Act was issued at the same time as the Clean Power Plan. ${ }^{78}$ Both are included in the revocation mandate contained in the Executive Order, which directs the EPA to 'immediately take all steps necessary to review' the regulations and any related rules and guidance for consistency with the general objective of 'avoiding regulatory burdens', and based upon the review, 'if appropriate' and 'as soon as practicable', to 'suspend, revise, or rescind the guidance, or publish for notice and comment proposed rules suspending, revising, or rescinding those rules. ${ }^{79}$ On the day the Executive Order was issued, the EPA began implementing it by withdrawing two proposed rules that were aimed at supplementing the Clean Power Plan ${ }^{80}$ and filing a motion with the US Court of Appeals for the DC Circuit to hold litigation against the rule in abeyance pending administrative action. ${ }^{81}$ On the same day, the EPA filed a notice that it is reviewing and, if appropriate,

64510. As with the Clean Power Plan, these New Source Performance Standards (NSPS) reflect the degree of emission limitation achievable through the application of the best system of emission reduction (BSER), but apply uniformly across the US, with a mandated rate of 1,000 lbs. of $\mathrm{CO}_{2}$ per $\mathrm{MWh}$ for stationary combustion turbines, generally firing natural gas; and a rate of 1,400 lbs. of $\mathrm{CO}_{2}$ per MWh for electric utility steam generating units, generally firing coal, a rate that would only be achievable using Carbon Capture and Sequestration (CCS) technology.

79 Executive Order 13783 (n 64) s 4.

80

EPA, 'Withdrawal of Proposed Rules: Federal Plan Requirements for Greenhouse Gas Emissions From Electric Utility Generating Units Constructed on or Before January 8, 2014; Model Trading Rules; Amendments to Framework Regulations; and Clean Energy Incentive Program Design Details' of 28 March 2017, 40 CFR Part 60 (2017) 82(62) Federal Register 16144; idem, 'Review of the Standards of Performance for Greenhouse Gas Emissions From New, Modified, and Reconstructed Stationary Sources: Electric Generating Units' of 4 April 2017, 40 CFR Part 60 (2017) 82(63) Federal Register 16330.

81 US Court of Appeals for the DC Circuit, State of West Virginia, et al, v EPA, et al, No 15-1363 (and consolidated cases), 'Notice of Executive Order, EPA Review of Clean Power Plan and Forthcoming Rulemaking, and Motion to Hold Cases in Abeyance' (28 March 2017); for more details, see infra, Section III.1. 
will initiate proceedings to suspend, revise or rescind the Clean Power Plan and new source performance standards. ${ }^{82}$

Additionally, the Executive Order mandates a review of rules aimed at reducing methane emissions from oil and gas operations and, if appropriate, their rescission or amendment. A series of related rules was issued by the previous administration as part of President Obama's 'Strategy to Reduce Methane Emissions' and the objective of reducing methane emissions from the oil and gas sector by 40 to $45 \%$ below 2012 levels by $2025 .{ }^{83}$ Methane, the main constituent of natural gas, has a significantly higher global warming potential than carbon dioxide, and its share in US GHG emissions is rising due to increased emissions from oil production as well as the production, processing, transmission and storage of natural gas. ${ }^{84}$ Among the regulations affected by the Executive Order is a rule that sets out performance standards for new, modified and reconstructed facilities in the oil and gas sector, defining best practices for monitoring and detecting leaks, preventing emissions and capturing fugitive gas. ${ }^{85}$ In early April, the EPA published a notice announcing that it is reviewing and, if appropriate, will initiate proceedings to suspend, revise or rescind that rule. ${ }^{86}$ Earlier in the year, the EPA Office of Air Quality Planning and Standards had already withdrawn an Information Collection Request (ICR) for methane emissions from the oil and gas industry, part of efforts by the previous administration to develop standards for natural gas leakage and flaring from existing facilities. ${ }^{87} \mathrm{~A}$ second regulation explicitly mentioned in the Executive Order seeks to curb methane waste from oil and natural gas development on federal land, and specifies limitations on gas flaring, improved leak detection and capture, and venting requirements. ${ }^{88}$ To date, the administration has not issued a notice announcing a review of this rule, but on 3 February 2017, the House of Representatives passed a resolution to repeal it using the CRA. ${ }^{89} \mathrm{~A}$ corresponding Senate resolution is still required before the disapproval can be submitted to the President for signature.

With the Executive Order, the new administration is also targeting executive and agency actions restricting the production of coal, oil, natural gas and shale energy. In particular, it instructs the Secretary of the Interior to amend or withdraw a Secretarial Order issued under the previous administration which called for a programmatic environmental review and modernisation of the federal coal leasing programme, and imposed a moratorium on federal land coal leasing based thereon. ${ }^{90}$ As of 2014, the Bureau of Land Management (BLM) administered coal leases on 475,692 acres of federal land, supplying approximately $40 \%$ of coal produced in the US. Concerns about fair return on these leases, the climate impacts of coal use, and deteriorating market conditions had prompted the previous administration to call for a comprehensive review of the federal coal leasing programme. Within a day after the Executive Order was signed by President Trump, Secretary of the Interior Ryan Zinke signed a Secretarial Order revoking the moratorium on federal coal leasing as well as the programmatic environmental review of
82 EPA, 'Review of the Clean Power Plan' of 4 April 2017, 40 CFR Part 60 (2017) 82(63) Federal Register 16329; the draft notice was filed on 28 March 2017, but published in the Federal Register one week later.

83 White House, 'Climate Action Plan: Strategy to Reduce Methane Emissions' (12 May 2016) <https://obamawhitehouse.archives .gov/sites/default/files/strategy_to_reduce_methane_emissions 2014-03-28_final.pdf $>$ accessed 27 March 2017.

84 EPA, 'Fact Sheet: EPA's Actions to Reduce Methane Emissions from the Oil and Natural Gas Industry: Final Rules and Draft Information Collection Request' 1 (2016) <http://www.epa.gov/ sites/production/files/2016-09/documents/nsps-overview-fs.pdf> accessed 29 March 2017.

85 EPA, 'Oil and Natural Gas Sector: Emission Standards for New, Reconstructed, and Modified Sources; Final Rule' of 3 June 2016 40 CFR Part 60 (2016) 81(107) Federal Register 35824; through these practices, the rule is projected to reduce annual GHG emissions by 11 million metric tons of $\mathrm{CO}_{2} \mathrm{e}$, see EPA, 'Fact sheet' (n 84) 4.
86 EPA, 'Review of the 2016 Oil and Gas New Source Performance Standards for New, Reconstructed, and Modified Sources' of , 40 CFR Part 60 (2017) Federal Register

87 EPA, Office of Air Quality Planning and Standards, Letter of 6 March 2017 <https://www.epa.gov/sites/production/files/2017-03/ documents/oil_and_gas_information_request_withdrawal_letter _sample_to_post_1.pdf> accessed 29 March 2017.

88 Department of the Interior, Bureau of Land Management (BLM), 'Waste Prevention, Production Subject to Royalties, and Resource Conservation' of 18 November 2016, 43 CFR Parts 3100, 3160 and 3170 (2016) 81(223) Federal Register 83008.

$89115^{\text {th }}$ Congress, HJRes. 36, 'Providing for Congressional Disapproval under Chapter 8 of Title 5, United States Code, of the Final Rule of the Bureau of Land Management relating to "Waste Prevention, Production Subject to Royalties, and Resource Conservation"' (3 February 2017).

90 Department of the Interior (DOI), Order No. 3338, 'Discretionary Programmatic Environmental Impact Statement to Modernize the Federal Coal Program' (15 January 2016), ss 4 and 5. 
the underlying programme. ${ }^{91}$ Another rule targeted by the Executive Order relates to hydraulic fracturing on federal and tribal lands, and imposes new requirements for wellbore integrity, water quality and public disclosure of hydraulic fracturing operations and chemical use. ${ }^{92}$ On 21 June 2016, the US District Court for Wyoming issued a decision setting aside the hydraulic fracturing rule, ${ }^{93}$ but that outcome was appealed by the previous administration; the current administration has since filed a motion with the US Court of Appeals for the $10^{\text {th }}$ Circuit to hold the case in abeyance pending administrative action, ${ }^{94}$ indicating its intention to issue a notice of proposed rulemaking to revise or rescind the hydraulic fracturing rule.

Finally, the Executive Order ends, with immediate effect, the use of the social cost of carbon as a metric to monetize the value of changes in GHG emissions from regulations, disbands the Interagency Working Group on Social Cost of Greenhouse Gases, and withdraws related technical support and update documents. ${ }^{95}$ Going forward, agencies will instead apply guidance on regulatory analysis issued by the Office of Management and Budget (OMB) during the presidency of George W. Bush, ${ }^{96}$ and, as the Executive Order further directs, 'with respect to the consideration of domestic versus international impacts and the con-

91 Department of the Interior (DOI), Order No 3348, 'Concerning the Federal Coal Moratorium' (29 March 2017), s 4

92 Department of the Interior (DOI), Bureau of Land Management (BLM), 'Oil and Gas; Hydraulic Fracturing on Federal and Indian Lands; Final Rule' of 20 March 2015, 43 CFR Part 3160 (2016) 80(58) Federal Register 16128.

93 US District Court of Wyoming, Wyoming et al $v$ Department of Interior, Case No 2:15-cv-00041-SWS (D Wyo filed 21 June 2016).

94 US Court of Appeals, $10^{\text {th }}$ Circuit, Wyoming et al $v$ Department of Interior, Nos. 16-8068, 16-8069, 'Federal Appellants' Motion to Continue Argument and Hold Case in Abeyance Pending Administrative Action' (15 March 2017).

95 Executive Order 13783 (n 64) s 5.

96 Office of Management and Budget (OMB), 'Circular A-4: To the Heads of Executive Agencies and Establishments. Subject: Regulatory Analysis.' (17 September 2003) <https://georgewbush -whitehouse.archives.gov/omb/circulars/a004/a-4.html> accessed 31 March 2017.

97 US Court of Appeals for the $9^{\text {th }}$ Circuit, Center for Biological Diversity v National Highway Traffic Safety Administration, F3d--, 2007 US App Case No 06-71891 (9th Cir, 15 November 2007).

98 For the year 2015, assuming a 3\% discount rate, see Interagency Working Group on Social Cost of Greenhouse Gases (IWG), 'Technical Support Document: Technical Update of the Social sideration of appropriate discount rates.' During the administration of President Barack Obama, the EPA and other federal agencies used an estimate of the social cost of carbon to calculate the benefits gained from a reduction in GHG emissions after a federal court ordered the practice in $2007 .{ }^{97}$ It represents a measure, in dollars, of the long-term damage done by a ton of $\mathrm{CO}_{2}$ emissions in a given year, and is currently set at $\$ 36$ per ton of $\mathrm{CO}_{2}{ }^{98}$ Under the traditional cost-benefit analysis federal agencies will now return to, the cost associated with GHG emissions is likely to be significantly lower, ${ }^{99}$ making it more difficult to argue net economic benefits from climate mitigation policies. A second and related provision in the Executive Order ${ }^{100}$ directs the Council on Environmental Quality (CEQ) to rescind guidance issued under the previous administration requiring federal agencies to consider climate change when conducting reviews under the National Environmental Policy Act (NEPA). ${ }^{101}$ In early April, the CEQ issued a notice announcing the withdrawal of this guidance. $^{102}$

Despite the sweeping scope of this Executive Order, the next section will argue that it may ultimately remain a symbolic measure by the administration that is likely to suffer lengthy procedural and judicial delays, its effectiveness limited by market dy-
Cost of Carbon for Regulatory Impact Analysis under Executive Order 12866' (August 2016). This figure is calculated using a complex, and controversial, set of models estimating future costs to society arising from the impacts of a changing climate, and then applying a discount rate to determine the net present value of limiting such future damages, see National Academies of Sciences, Engineering, and Medicine, Valuing Climate Damages. Updating Estimation of the Social Cost of Carbon Dioxide (National Academies Press 2017).

99 Especially if international impacts are disregarded and a higher discount rate applies, as the Executive Order indicates; the conventional approach to cost-benefit estimates described in the $\mathrm{OMB}$ guidance document focuses on domestic impacts and excludes damages that are incurred outside the US, whereas the IWG that elaborated the social cost of carbon decided that, because climate change is a global concern, global impacts would be taken into account.

100 Executive Order 13783 (n 64) s 3(c).

101 Council on Environmental Quality (CEQ), 'Final Guidance for Federal Departments and Agencies on Consideration of Greenhouse Gas Emissions and the Effects of Climate Change in National Environmental Policy Act Reviews' of 1 August 2016 (2016) 81(51) Federal Register 51866.

102 Council on Environmental Quality (CEQ), 'Withdrawal of Final Guidance for Federal Departments and Agencies on Consideration of Greenhouse Gas Emissions and the Effects of Climate Change in National Environmental Policy Act Reviews' of 5 April 2017 (2017) 82(64) Federal Register 16576. 
namics and continued state and local action; and that it yet may be, at the same time, an astute political maneuver that sends important signals to climate policy advocates both domestically and abroad.

\section{Analysis}

\section{Means as an End: Procedural Inertia and Litigation}

As outlined in the preceding section, executive action taken so far by the current administration on climate change has a clear center of gravity on unravelling policies set in place by the previous administration. Even where those policies were implemented by way of agency regulations rather than statutory legislation, which - given the partisan rift on climate change in both chambers of Congress - is the case with a majority of climate measures taken during the presidency of Barack Obama, repealing his climate legacy will not be an expeditious and straightforward process. Alternative pathways exist to undo the current climate policy framework, but each is subject to detailed procedural requirements and constraints.

For regulatory action taken within 60 legislative days of the end of the last congressional session, the CRA allows Congress to pass a joint resolution with simple majority votes in both chambers to 'disapprove' regulatory action taken during the first 75 days of the next session. ${ }^{103}$ To date, the $115^{\text {th }}$ Congress has successfully applied this process with greater frequency than any previous Congress since enactment of the provision over two decades ago. ${ }^{104}$ Once disapproved, the CRA also prohibits reissuing the rule in substantially the same form or issuing a new rule that is substantially the same, 'unless the reissued or new rule is specifically authorized by a law enacted after the date of the joint resolution disapproving the original rule. ${ }^{105}$ Despite its conclusive effect, the applicability of this process is limited: only agency rules finalised by the previous administration on or after 13 June 2016 can be subjected to the expedited review, ${ }^{106}$ and the opportunity to do so will close once the $115^{\text {th }}$ Congress exceeds 75 days in session. After that, Congress can still pass substantive legislation to repeal or revise agency rules or indeed the legislation that sets out the rulemaking authority underlying such rules. In both cases, howev- er, Senate cloture and filibuster rules require a higher voting threshold of 60 votes to move such legislation to a vote, ${ }^{107}$ provided the Senate does not invoke a procedure that allows overriding any rule or precedent by a simple majority of $5^{1}$ votes. ${ }^{108} \mathrm{Ap}$ propriation bills on discretionary spending are another exception where Congress could pass a final budget proposal from the administration with a simple majority. But while this process could effectively be used to defund an agency such as the EPA, it would prove politically contentious and may incite litigation.

Absent congressional repeal, the administration can overturn certain measures itself through executive action. A majority of the Executive Orders described in the previous section direct federal agencies to review and, if appropriate, initiate proceedings to suspend, revise or rescind various guidelines, orders and regulations adopted during the previous administration. For instance, the Executive Order on 'Promoting Energy Independence and Economic Growth' calls upon the EPA to review and potentially suspend, revise or rescind the Clean Power Plan, ${ }^{109}$ prompting the agency to publish a notice

103 Congressional Review of Agency Rulemaking (n 56) § 802(a).

104 See, for instance, 115th Congress HJRes 38 (n 57) and 115th Congress HJRes 36 (n 89) above regarding the 'Stream Protection Rule' $^{\prime}$ and the BLM regulation curbing methane emissions from federal lands; an additional rule that has been repealed under the CRA would have required US energy companies to disclose payments made to governments for the commercial development of oil, natural gas, or minerals, see Securities and Exchange Commission (SEC), 'Disclosure of Payments by Resource Extraction Issuers' of 27 July 2016, 17 CFR Parts 240 and 249b (2016) 81(144) Federal Register 49359 , repealed by $115^{\text {th }}$ Congress, HJRes41, 'Providing for Congressional Disapproval under Chapter 8 of Title 5, United States Code, of a Rule Submitted by the Securities and Exchange Commission relating to "Disclosure of Payments by Resource Extraction Issuers"' (14 February 2017) Publ L 115-4.

105 Congressional Review of Agency Rulemaking (n 56) § 801(b)(2).

106 Christopher M Davis and Richard S Beth, 'Agency Final Rules Submitted on or After June 13, 2016, May Be Subject to Disapproval by the 115th Congress' (CRS Insight, 15 December 2016) $<$ https://fas.org/sgp/crs/misc/IN10437.pdf> accessed 29 March 2017.

107 US Senate, Rules of the Senate, 'Precedence of Motions (Rule XXII)': 'three-fifths of the Senators duly chosen and sworn.'

108 A controversial procedure, known as the 'constitutional' or 'nuclear option', that has rarely been invoked and is considered vital to protect bipartisanship in the Senate; for background, see Betsy Palmer, 'Changing Senate Rules: The "Constitutional" or "Nuclear" Option' (Congressional Research Service, 26 May 2005) <http://research.policyarchive.org/176.pdf> accessed 29 March 2017.

109 Executive Order 13783 (n 64) s 4. 
announcing such a review, providing advanced notice of forthcoming rulemaking proceedings, and setting out principles that it will consider in the process. ${ }^{110}$ Should the administration, based on the review in this and any other cases, decide to suspend, revise or rescind existing regulations, it will have to adhere to an established procedure. Under the Administrative Procedure Act and specialised statutes such as the Clean Air Act, proposed rules suspending, revising, or rescinding existing rules have to be published for notice and comment, ${ }^{111} \mathrm{a}$ protracted process that can require three to six months to complete and result in considerable public input. ${ }^{112}$ What follows is the preparation of a final rule, with any necessary revisions, along with development of appropriate responses to public comments, continued stakeholder engagement, and legal and policy review of the rule, adding up to two more years to the process. ${ }^{113} \mathrm{~A}$ less onerous process applies to actions that did not go through formal notice and comment proceedings, such as Executive and Secretarial Orders, guidelines and reports, all of which can be revoked with immediate effect by executive fiat.

While the ability of federal agencies to revisit existing regulations, including authority to reconsider

110 EPA, 'Review of the Clean Power Plan' (n 82); guiding principles the EPA will apply include: determining whether the Clean Power Plan is appropriately grounded in EPA's statutory authority and consistent with the rule of law; whether it appropriately promotes cooperative federalism and respects the authority and powers that are reserved to the states; whether it effects the administration's dual goals of protecting public health and welfare while also supporting economic growth and job creation; whether it appropriately maintains the diversity of reliable energy resources and encourages the production of domestic energy sources to achieve energy independence and security; and whether the rule and alternative approaches will provide benefits that substantially exceed their costs.

$1117^{\text {th }}$ Congress, S7, 'An Act to Improve the Administration of Justice by Prescribing Fair Administrative Procedure' (11 June 1946) Pub L 79-404, 60 Stat 237, US Code Title 5 Part I Chapter $5 \S 553$; a limited exception to the need for notice and comment applies under $\$ 553$ (b) where an agency finds good cause that related procedures 'are impracticable, unnecessary, or contrary to the public interest', but this generally only covers situations of great urgency.

112 In the case of the Clean Power Plan, for instance, the EPA received 4.3 million public comments, see EPA, 'Fact Sheet: Clean Power Plan by the Numbers' (3 August 2015) <https://www.epa .gov/sites/production/files/2015-08/documents/fs-cpp-by-the -numbers.pdf> accessed 29 March 2017.

113 Thomas A Lorenzen and Sherrie A Armstrong, 'Change in Administrations, Change in Course? What the Next President Could Do to Vacate or Reform Obama's Clean Power Plan (Part 2 of 2)' (Trends 48(2), November/December 2016) < http://www .americanbar.org/publications/trends/2016-2017/november and rescind or revise past decisions, has been affirmed with ample judicial precedent, such action must be supported by a 'reasonable explanation' and demonstrate that 'there are good reasons for the new policy. ${ }^{114}$ In effect, ruling on a regulatory reversal during the presidency of Ronald W Reagan, the Supreme Court required that ' $[\mathrm{a}] \mathrm{n}$ agency changing its course by rescinding a rule is obligated to supply a reasoned analysis for the change beyond that which may be required when an agency does not act in the first instance. ${ }^{115}$ This is generally interpreted to mean that the agency must examine the relevant data and articulate a satisfactory explanation for its action, building a robust record of scientific, economic, and other supporting information. In order to rescind the Clean Power Plan, for instance, the EPA would have to establish that rescission of the rule is not contrary to the Clean Air Act, is reasonable, and does not endanger public health or welfare. As long as the endangerment finding for GHG emissions ${ }^{116}$ adopted during the previous administration remains in place - and none of the executive actions of the current administration have suggested repealing it, a process that would entail its own challenges ${ }^{117}$ the EPA would have to establish new emission guidelines, although it could then assume a more modest

-december-2016/change_in_administrations.html> accessed 29 March 2017.

114 See US Supreme Court, Federal Communications Commission (FCC) v Fox Television Stations, Inc, 556 US 502, 515 (S Ct 28 April 2009).

115 US Supreme Court, Motor Vehicle Manufacturers Association of the United States Inc et al, v State Farm Mutual Automobile Insurance C, et al, 463 US 29, 42 (S Ct 24 June 1983), para (a). See also Merrick B Garland, 'Deregulation and Judicial Review' (1985) 98 Harv L R 507.

116 EPA (n 40)

117 Simply withdrawing the finding would violate the Supreme Court ruling in Massachusetts et al $v$ EPA (n 40). It would have to be replaced with a new finding supported by a similarly voluminous scientific foundation as that underlying the original endangerment finding, which was based on the scientific research com piled by, inter alia, the Intergovernmental Panel on Climate Change (IPCC), the US Global Climate Research Programme and the National Research Council. The endangerment finding was upheld by the US Court of Appeals for the DC Circuit in 2012, when the court found that the EPA's interpretation of its authority and of its obligation to regulate carbon dioxide 'is unambiguously correct', US Court of Appeals for the DC Circuit, Coalition for Responsible Regulation, Inc, et al, v EPA, et al, No 09-1322 (DC Cir, 26 June 2012). Recently, however, Pruitt has come under increasing pressure from the right to repeal the endangerment finding as the basis for much of the regulatory action his agency has issued, see Coral Davenport, 'Scott Pruitt Faces Anger From Right Over E.P.A. Finding He Won't Fight' (New York Times, 12 April 2017). 
'best system of emissions reduction', or grant states the ability to seek more exemptions. ${ }^{118}$ Even then, the new standards would have to be justified with reasoning based on the provisions of Clean Air Act or risk being considered 'arbitrary and capricious ${ }^{\prime 119}$ and thus failing judicial scrutiny. ${ }^{120}$ Only if a federal court rules that the EPA lacks authority to regulate GHG emissions from existing sources - an argument cited by several petitioners in litigation to set aside the Clean Power Plan ${ }^{121}$ - would a rescission without replacement be admissible, yet it would still not affect the obligation of the EPA to address emissions from new stationary sources and mobile sources.

Where regulations are currently subject to pending litigation, as is the case with the Clean Power Plan, the administration effectively has an additional venue to stall or repeal climate regulations. Within months of its release, the Clean Power Plan became the most heavily litigated federal environmental regulation in US history, ${ }^{122}$ with lawsuits from - at one point -27 states as well as countless other petitioners, such as energy companies and local electric utilities, rural electric cooperatives, labour unions, industry and trade associations, and additional stakeholders challenging the legality of the rule and accusing the administration of regulatory overreach; meanwhile, a large number of intervenors and amici curi-

118 While still Attorney General of Oklahoma, Scott Pruitt issued a plan to replace the Clean Power Plan with a framework that would have only called for emissions reductions achievable 'inside the fenceline' at individual power plants (which would include heat rate improvements, but not fuel switching), and would have required states to to adopt such federal standards unless the state determined that circumstances justified the imposition of a less stringent emission standard, rendering the standards more an aspirational guideline than a binding requirement, see E Scott Pruitt, 'The Oklahoma Attorney General's Plan: The Clean Air Act Section 111(d) Framework that Preserves States' Rights' (April 2014) <http://assets.documentcloud.org/documents/3444765/Scott -Pruitt-Clean-Air-Act-States-Rights.pdf> accessed 29 March 2017.

119 Administrative Procedure Act (APA) (n 111) § 706(2)(A).

120 Supreme Court ( $\mathrm{n}$ 40); in the ruling on Massachusetts et al V EPA, the court affirmed that decisions not to regulate cannot rest on 'reasoning divorced from the statutory text', and that the EPA must 'ground its reasons for action or inaction in the statute' and 'exercise its discretion within defined statutory limits.'

121 US Court of Appeals for the DC Circuit, Docket for State of West Virginia, et al, V EPA, et al, No 15-1363 (and consolidated cases) (DC Cir, 23 October 2015); one argument, based on divergences in the House and Senate bills that amended the Clean Air Act in 1990 and were never reconciled, is that $\$ 111$ (d) of the Clean Air Act cannot serve as a basis for regulation of existing power plants because these already are subject to rules on mercury pollution under $\$ 112$. $a e$ - including states, counties and municipalities, former cabinet members and more than half of all current Members of Congress - filed briefs supporting or opposing the foregoing petitions. ${ }^{123}$ After the US Court of Appeals for the District of Columbia Circuit consolidated these petitions into one case, ${ }^{124}$ an interlocutory application resulted in the US Supreme Court staying implementation of the Clean Power Plan on 9 February 2016 until a lower court issues a ruling on the merits of the case. ${ }^{125}$ So far, no ruling has been made, ${ }^{126}$ and President Trump's Executive Order affords the Attorney General discretion to request a stay of the litigation or seek other appropriate relief pending reconsideration of the Clean Power Plan by the EPA. ${ }^{127}$

On the same day as the Executive Order was signed, the administration filed a motion with the court to hold litigation against the rule in abeyance pending administrative action, asking for a standstill 'until 30 days after the conclusion of review and any resulting forthcoming rulemaking. ${ }^{128}$ Such a voluntary remand could be denied by the court, however, which might allow the case to continue on its merits until formal withdrawal of the contested rule. Alternatively, the new administration could have admitted error and asked the court to vacate the Clean Power Plan or simply declined to defend it, obviating the lengthy procedure needed to rescind the rule by way

122 Samuel Kernell, Gary C Jacobson, Thad Kousser and Lynn Vavreck, The Logic of American Politics ( th $^{\text {th }}$ edn, CQ Press 2018) 83.

123 For an overview, see Linda Tsang and Alexandra M Wyatt, 'Clean Power Plan: Legal Background and Pending Litigation in West Virginia v EPA' 10-2 (Congressional Research Service, 8 March 2017) <https://fas.org/sgp/crs/misc/R44480.pd > accessed 29 March 2017.

124 State of West Virginia, et al, v EPA, et al (n 121).

125 US Supreme Court, State of West Virginia, et al, v EPA, et al, Order in Pending Case, No 15A773 (S Ct 9 February 2016) $<$ https://www.supremecourt.gov/orders/courtorders/020916zr4_4g15.pdf> accessed 29 March 2017. This decision marks the first time that the Supreme Court has stayed or enjoined a final agency rule where a lower court had, after briefing, declined to do so. Justice Antonin Scalia death four days later, on 13 February 2016, would have likely resulted in a split decision, uphold the decision of the US Court of Appeals for the DC Circuit to deny the stay.

126 On 27 September 2016, the US Court of Appeals for the DC Circuit heard oral argument en banc, but a ruling is still pending.

127 Executive Order 13783 (n 64) s 4(d).

128 US Court of Appeals for the DC Circuit (n 81) 
of executive action. But judicial precedent suggests a motion to vacate would be denied, ${ }^{129}$ and the intervenors in support of the rule would also likely continue to defend the rule. Indeed, on 5 April 2017, a coalition of 17 states, six municipalities and the District of Columbia filed opposition to the motion to hold the cases in abeyance, arguing that the case is ripe for decision now' and that a decision from the court would 'resolve critical live disputes over the scope of the Clean Air Act that will not only determine the enforcement of the Clean Power Plan, but also affect any reconsideration or revision of the Rule that EPA may undertake. ${ }^{, 130}$ Among the main issues at dispute is whether the Clean Air Act affords the EPA authority to regulate emissions from existing sources under more than one provision, and whether the 'best system of emissions reduction' can be based on actions that cannot be taken by each compliance entity alone, such as shifting dispatch from coal- to gas-fired electricity generation.

Finally, the administration could seek to undermine the effect of President Obama's regulatory legacy by exercising its discretionary enforcement powers and refusing to enforce compliance obligations. In that case, however, the regulations would remain in full effect, affording stakeholders and other persons standing to initiate judicial proceedings - for

129 A district court ruling in National Parks Conservation Association $\checkmark$ Salazar, Case No. 1:09-cv-00115 (12 August 2009) held that vacatur was not appropriate absent a merits ruling, significant new evidence, or the agreement of all parties, and that otherwise it would 'wrongfully permit the Federal defendants to bypass established statutory procedures for repealing an agency rule' under the Administrative Procedure Act (APA), see idem 4-5.

130 US Court of Appeals for the DC Circuit, State of West Virginia, et al, v EPA, et al, No 15-1363 (and consolidated cases), 'State and Municipal Respondent-Intervenors' Opposition to Motion to Hold Proceeding in Abeyance' (5 April 2017).

131 Lorenzen et al (n 113).

132 While power has gradually shifted away from the states and towards the federal government under a number of constitutional doctrines, such as the dormant commerce clause, the compact clause, or foreign affairs preemption, a basic principle of American federalism, set out in the Tenth Amendment, remains that the 'powers not delegated to the United States by the Constitution, nor prohibited by it to the States, are reserved to the States respectively, or to the people.' For further details, see Daniel A. Farber, 'Climate Change, Federalism, and the Constitution' (2008) 50 Ariz L R 879.

133 For an overview, see Michael Mehling and David J Frenkil, 'Climate Law in the United States: Facing Structural and Procedural Limitations' in Erkki J Hollo, Kati Kulovesi and Michael Mehling (eds), Climate Change and the Law (Springer 2013) 480-81.

134 Barry Rabe, 'Contested Federalism and American Climate Policy' (2011) 41 Publius 494.

135 Bloomberg (n 68). instance a citizen suit under Section 304(a) of the Clean Air Act - against the relevant agency or alleged violators to enforce those obligations. Also, while laxity in the enforcement of environmental rules has been used as a political strategy under earlier administrations, it has practical limitations, as most companies in affected sectors will still follow the law and protect their public reputation. A casual approach to enforcement will therefore only afford partial relief to compliance entities, and entail new and undesirable uncertainty. ${ }^{131}$

\section{Limits to Federal Power: The Role of States and Markets}

For all the discussion about the scope of regulatory rollback facing US climate policy, it is also important to bear in mind the constitutional limits on federal powers in the area of climate change, as well as the role of market dynamics and fundamentals in driving the reduction of carbon emissions in North America.

Under the US Constitution, both the federal and state governments enjoy some exclusive powers in the areas of energy and environmental policy, and exercise other powers in common. ${ }^{132}$ As a result, climate legislation and executive rulemaking in the US form part of a dynamic and evolving tapestry of federal, state and local action, ${ }^{133}$ with a periodically shifting locus of progressive climate ambition. ${ }^{134}$ Many policies that are driving GHG emissions reductions across North America, such as binding mitigation targets, renewable portfolio standards and energy efficiency standards, have been adopted at the state level, while federal policy - with the exception of international diplomacy - arguably played only a limited role until well into the first term of President Obama. Previously, the US had no federal climate targets, and between periods of federal inaction and time lost over failed attempts to pass federal climate legislation, progressive states and municipalities inevitably rose to fill the policy vacuum.

More recently, federal action - and especially executive rulemaking - have gained in importance, as is evidenced by the contested climate policy legacy of the Obama administration, but with pivotal elements of that legacy not yet or just recently entered into force, the importance of federal climate policy in the Madisonian polity of the US can be easily overstated. ${ }^{135}$ This point is further reinforced by the ob- 
servation that GHG emissions in North America have declined significantly in recent years, dropping $11.2 \%$ between 2005 and $2015,{ }^{136}$ even as many federal climate policies have yet to exert a noticeable effect. But it would also be misguided to dismiss the role of federal action in limiting emissions from federal lands and buildings, as well as the activities of the various branches of government, including the military. And although less tangible, the signalling effect of federal policy direction in shaping expectations of the private sector can be critical for sound strategic planning and investment choices compatible with the long time horizon of decarbonisation. Altogether, the various ways in which federal policy nonetheless affects US emissions have prompted analysts to project that the regulatory rollback pursued by the Trump administration will slow down emissions reductions from $21 \%$ to $14 \%$ below 2005 emissions by $2025 .{ }^{137}$

Still, the outsized influence of dynamic market forces on changes in US emissions should not be ignored, and may ultimately disprove conservative forecasts as it has so frequently in the past. ${ }^{138}$ Outpacing overall emissions abatement, emissions from electricity generation are currently at their lowest level since 1993, another major trend not predicted only some years ago. Over two thirds of those reductions are ascribed to fuel switching from coal to natural gas, a result of falling gas prices made possible by the rapid growth in supply from increasingly ef-

136 EPA, 'Draft Inventory of U.S. Greenhouse Gas Emissions and Sinks: 1990-2015' 10 (15 February 2017) <https://www.epa.gov/ sites/production/files/2017-02/documents/2017_complete_report .pdf> accessed 29 March 2017.

137 John Larsen, Kate Larsen, Whitney Ketchum, Shashank Mohan, and Trevor Houser, 'Trump's Regulatory Rollback Begins' (27 March 2017) <http://rhg.com/notes/trumps-regulatory-rollback -begins> accessed 29 March 2017.

138 See, eg, Sergey V Paltsev, 'Energy Scenarios: The Value and Limits of Scenario Analysis' (2017) WIREs Energy and Environment, forthcoming.

139 Energy Information Administration (EIA), 'U.S. Energy-related Carbon Dioxide Emissions in 2015 are 12\% Below Their 2005 Levels' (9 May 2016) <https://www.eia.gov/todayinenergy/detail .php?id=26152> accessed 29 March 2017; idem, 'Carbon Dioxide Emissions from Electricity Generation in 2015 Were Lowest Since 1993' (13 May 2016) <https://www.eia.gov/todayinenergy/ detail.php?id=26232> accessed 29 March 2017. A recent downturn in oil prices forced the US hydrocarbon industry to improve the efficiency of its operations, helping breakeven costs on shale oil and gas wells to drop by an average of $22 \%$ per year since 2013, see Rystad Energy, 'Average Shale Wellhead Breakeven Prices Are Below 40 USD/BBL' (28 July 2016) < https://www .rystadenergy.com/NewsEvents/PressReleases/shale-well -breakeven> accessed 29 March 2017.

140 Coal had been seeing a steep decline in jobs across its supply chain well before the Obama administration began implementing ficient hydraulic fracturing practices. ${ }^{139}$ A corollary of this competition between coal and gas is falling demand for coal, which has declined $27 \%$ since 2005 and significantly weakened the coal mining industry, along with its employment potential. ${ }^{140}$ Given that many executive actions surveyed earlier in this article directly promote the production and use of hydrocarbons, including shale gas, it is difficult to see how President Trump can nonetheless achieve his campaign promise of spurring a revival of the coal sector. ${ }^{141}$

Adding to the competitive pressures facing coal is another sector in which innovation and scale are rapidly lowering prices: renewable energy. In 2016 alone, the US saw installation of nearly $15 \mathrm{GW}$ of new solar photovoltaic generating capacity, outpacing any other source of new generation. ${ }^{142}$ With deployment increasingly independent from policy support, movement by many US states to expand their renewable energy mandates, and public investment in research and development continuing in other parts of the world even as the US might cut back federal funds, the global market for renewable energy is unlikely to lose momentum. If any single technology will suffer from a potential rescission or weakening of the Clean Power Plan, it is nuclear energy, which is likewise facing competitive pressures and would have stood to benefit from the regulatory incentive for low-carbon energy generation. ${ }^{143}$

climate regulations, see eg Drew Haerer and Lincoln Pratson, 'Employment Trends in the U.S. Electricity Sector, 2008-2012' (2015) 82 Energy Policy 85. A recent calculation by the Sierra Club estimates that jobs in renewable energy already outnumber all fossil fuel jobs by over 2.5 to 1 nationally, see Sierra Club, 'Clean Energy Jobs Overwhelm Coal, Oil \& Gas in 41 States and D.C.' (27 March 2017) <http://www.eenews.net/assets/2017/03/ 27/document_gw_04.pdf> accessed 29 March 2017.

141 As Vaclav Smil has described it, '[ $t$ ] he retreat from American coal mining was not caused by President Barack Obama's environmental regulations or by any ideological dislike of the fuel that provided the energy foundations of modern civilization. The history of energy use is a sequence of transitions to sources that are cheaper, cleaner and more flexible.' idem, 'Trump's Coal Policy Will Likely Do Just What Obama's Did' (Washington Post, 29 March 2017).

142 Solar Energy Industries Association (SEIA) and GTM Research, 'U.S. Solar Market Insight 2016 Year in Review' (9 March 2017) <http://www.greentechmedia.com/research/subscription/u.s.-solar -market-insight> accessed 29 March 2017.

143 A large portion of the US nuclear fleet is approaching the end of its normal operating lifespan, with eight plants providing about 9.3 GW of generating capacity subject to retirement over the next few years, see Jim Krane and Elsie Hung, 'United States' Energy and Climate Policy under President Trump: Ramifications for Energy Markets and the GCC' (Emirates Diplomatic Academy, February 2017) <http://www.eda.ac.ae/images/pdf/ EDAInsightUSEnergyClimatePolicyTrumpEN.pdf > accessed 29 March 2017. 
Adding the risk that future administrations will reinstate any carbon constraints withdrawn by the Trump administration, ${ }^{144}$ it is unsurprising that utilities mostly expect a sustained transition to renewable energy and natural gas, and are planning their investment decisions accordingly. ${ }^{145}$ Overall, the federal climate regulations that now stand to be reviewed and possibly withdrawn are not, thus, the main drivers of recent US renewable energy growth and GHG emissions reductions as much as shifting market fundamentals and state action. In fact, even before the Clean Power Plan could take effect, a majority of states - including several states that have been strongly opposed to the regulation and joined judicial proceedings against it - had been on track to achieving their state targets, again driven mostly by subnational policies and market forces. ${ }^{146}$ Multiple interrelated uncertainties will make it difficult or even impossible to determine the precise extent, but there is definitely truth to the argument that much of President Obama's climate legacy merely traced and locked in fundamental trends that were already underway. ${ }^{147}$

On the margin, admittedly, regulatory relief from the reform agenda of the current administration may make some coal companies economically more vi-

144 Jim Krane, 'Climate Risk and the Fossil Fuel Industry: Two Feet High and Rising' (Baker Institute for Public Policy, July 2016) <https://scholarship.rice.edu/handle/1911/91261> accessed 29 March 2017

145 Utility Dive, 'State of the Electric Utility Survey 2017' (28 March 2017) <http://s3.amazonaws.com/dive_assets/rlpsys/SEU_2017 .pdf > accessed 29 March 2017.

146 Nicholas Bianco, Tomás Carbonell and Martha Roberts, 'Clean Power Plan Compliance Within Reach for Litigating Companies' (Environmental Defense Fund, 26 September 2016) <http://www .edf.org/sites/default/files/content/2016-09-26_edf_fact_sheet --_power_companies_opposing_final.pdf> accessed 29 March 2017.

147 Eric Holthaus, 'Buried in Obama's Climate Plan: A Promise of Business as Usual to the Fossil Fuel Industry' (Slate, 4 August 2015) <http://www.slate.com/blogs/the_slatest/2015/08/04/ obama_s_clean_power_plan_analysis_business_as_usual_for_the fossil fuel.html> accessed 1 April 2017. Holthaus cites a passage in the Clean Power Plan rule, EPA (n 73) 636, which expressly concedes that it is 'fully consistent with the recent changes and current trends in electricity generation, and as a result, would by no means entail fundamental redirection of the energy sector'.

148 Energy Information Administration (EIA), 2 'Short-Term Energy Outlook (STEO)' (11 April 2017) <https://www.eia.gov/outlooks/ steo/pdf/steo_full.pdf> accessed 11 April 2017.

149 United Nations Framework Convention on Climate Change (UNFCCC), New York (9 May 1992, in force 21 March 1994) (1992) 31 ILM 849

150 Trump (n 3). able, and may help delay the retirement of older thermal generation capacity. Increased exports of liquefied natural gas (LNG) may also result in higher domestic prices, temporarily reversing some of the fuel switching effects observed in recent years. ${ }^{148}$ Should that trend amplify over time, rules like the Clean Power Plan and the New Source Performance Standards would have played an important, but ultimately hypothetical, role as hedges against a coal revival driven by evolving market fundamentals. Still, it does not negate the argument that federal climate regulations played a subordinate role to market dynamics and state or local action in driving recent emission reductions. For international observers, that may provide scarce consolation, given how much less predictable and properly documented these latter factors are. Annulment of regulations such as the Clean Power Plan may therefore have a greater impact on the political dynamics of international climate cooperation than is warranted by their actual mitigation effect, a possibility discussed in the next subsection.

\section{International Cooperation and the Paris Agreement}

In contrast to its restless pace when it comes to rolling back domestic climate polices, the new administration has offered far less guidance on the future direction of foreign policy and international cooperation. US bilateral engagement with China in recent years is often credited with facilitating passage of the Paris Agreement, adding that breakthrough in international climate diplomacy to the legacy of former President Obama. Despite the uncertainties, it can be safely assumed that the administration of President Trump will not extend this legacy of climate leadership. In fact, rhetoric from the election campaign seemed to indicate a full US withdrawal from the international climate process operating under the auspices of the United Nations Framework Convention on Climate Change (UNFCCC): ${ }^{149}$ on various occasions, such as during his campaign speech in Bismarck, ND, candidate Trump had announced he would 'cancel' the Paris Agreement and withhold all contributions to international climate funds. ${ }^{150}$

Likewise, several members of his transition team and wider advisory circle made no secret about their 
preferred course of action: full withdrawal from the international climate process. ${ }^{151}$ Given the nationalist and protectionist narratives invoked throughout the election campaign, such a withdrawal would also be consistent with the rejection of more globalist foreign policies espoused by Donald Trump's recent predecessors, both in Democratic and Republican administrations. But aside from some internal staffing and workflow decisions ${ }^{152}$ and the budget blueprint, which calls for ceasing 'payments to the United Nations' (UN) climate change programs, ${ }^{153}$ and will still see extensive amendments as it passes through Congress, there has yet to be a clear statement from the White House about whether the US will formally renounce the Paris Agreement and the broader climate regime, or remain - possibly passive - participants.

Different pathways can lead to a formal withdrawal from the climate regime. For the Paris Agreement, the process is detailed in Article 28, which allows parties to pull out at 'any time after three years' from the date on which the agreement entered into force for them, with effect 'upon expiry of one year from the date of receipt ... of the notification of withdrawal. ${ }^{154}$ Given that the Paris Agreement entered into force for the US on 4 November 2016, the earliest date by which the latter could notify its intention to withdraw would be 4 November 2019, allowing the withdrawal to take effect on 4 November 2020, towards the end of President Trump's current term in office. Alternatively, the US could formally withdraw from the UNFCCC pursuant to its Article 25, which

151 See, eg, Osorio et al (n 4) (regarding Myron Ebell); Surgey (n 4) (regarding Thomas Pyle); Nicolas D Loris, Brett D Schaefer and Steven Groves, 'The U.S. Should Withdraw from the United Nations Framework Convention on Climate Change' (Heritage Foundation, 9 June 2016) <http://www.heritage.org/environment/ report/the-us-should-withdraw-the-united-nations-framework -convention-climate-change> accessed 29 March 2017, citing 'wasted taxpayer money, higher energy prices, and special treatment ... for preferred energy sources and technologies' as well as uncertainties in climate science as reasons for formal withdrawal from the UNFCCC, and also suggesting that extant US law prohibits funding the UNFCCC after the Palestinian Authority acceded in March 2016, under US Code Title 22, Section 287e (Publ L 103-236, 1994): 'The United States shall not make any voluntary or assessed contribution: (1) to any affiliated organization of the United Nations which grants full membership as a state to any organization or group that does not have the internationally recognized attributes of statehood.'

152 Within the State Department, the position of Special Envoy for Climate Change will likely be eliminated going forward; the appointee to this role helped lead international negotiations during the previous administration. Instead, work on international climate policy has apparently been largely ceded to the White House, see Nahal Toosi and Andrew Restuccia, Nervous State Department Workers Prepare for Major Restructuring' (Politico, 9 describes a very similar process. Because the UNFCCC has been in force for the US since 21 March $1994,{ }^{155}$ the withdrawal could be notified immediately, allowing it to take effect within one year. Both treaties specify that a withdrawal from the UNFCCC - as the 'mother convention' - will also entail automatic withdrawal from its subsidiary treaties, which includes the Paris Agreement. Although some commentators have suggested that exiting the UNFCCC constitutes 'an executive branch power' that does not require Congressional approval or ratification, ${ }^{156}$ it bears remembering that the UNFCCC was ratified unanimously by the US Senate, suggesting that the domestic procedure will depend on whether a withdrawal is considered a 'political question' and thus a prerogative of the President, or whether the same Senate voting procedure that already governed the original ratification applies. ${ }^{157}$ Rather than withdraw, the US could also significantly weaken its pledged mitigation effort, although this would arguably violate the progression duty under the Paris Agreement. ${ }^{158}$

Finally, an informal option for the US to disengage from the international climate regime would consist in simply ignoring the voluntary pledges made under the Paris Agreement, and adopting a passive or obstructionist approach to participation.

If the new administration chooses any of the foregoing options, and especially if it opts for a formal withdrawal from the UNFCCC, it will likely incur a substantial diplomatic cost. Such a move might dam-

April 2017) <http://www.politico.com/story/2017/04/state -department-cuts-restructuring-236796> accessed 29 March 2017.

153 Executive Office (n 23) 33.

154 See Decision 1/CP.21, Adoption of the Paris Agreement, Annex, UN Doc FCCC/CP2-15/10/Add.1 (29 January 2016) art 28 (1) and (2).

155 UNFCCC, 'Status of Ratification of the Convention' (no date) <http://unfccc.int/essential_background/convention/status_of _ratification/items/2631.php > accessed 29 March 2017.

156 Loris et al (n 149) 10

157 See the 'political question doctrine' established by the Supreme Court in Goldwater v Carter (1979), 444 U.S. 996, regarding the President's power to unilaterally nullify the Sino-American Mutual Defense Treaty. Under Article II Section 2 of the US Constitution, which states that ' $\mathrm{t}$ ] he President ... shall have power, by and with the advice and consent of the Senate, to make treaties, provided two thirds of the Senators present concur', ratification of the UNFCCC on 15 October 1992 required a $2 / 3^{\text {rds }}$ supermajority in the Senate.

158 See art 4(3) and (11) of Decision 1/CP.21 (n 154). 
age the international reputation of the US and its perceived reliability as an international actor, and repercussions might even spill over into other policy agendas in which the current administration has a stronger interest, such as trade, immigration or defence. ${ }^{159}$ One question that will invariably emerge in light of the domestic climate policy reversal is whether the US can achieve its pledged contribution of reducing US GHG emissions in 2025 by $26 \%$ to $28 \%$ compared to 2005 levels, ${ }^{160}$ something observers have said to be contingent on full implementation of the Clean Power Plan and a suite of other Obama-era policies now threatened with rescission. ${ }^{161}$

Whether lacking ambition by the US might provide an excuse for other countries to ignore their commitments or weaken future pledges, as some fear, ${ }^{162}$ is difficult to predict. Several influential actors in international climate diplomacy, including China and India, have at least verbally stated an intention to uphold their climate ambitions irrespective of continued US participation. ${ }^{163}$ Absent US leadership on climate change, other nations might even seek to fill the ensuing void: Europe may be too preoccupied with internal crises to resume its earlier role as a champion of international climate policy ambition, ${ }^{164}$ but emerging nations such as China might perceive a stronger role in the process as a strategic opportunity. ${ }^{165}$ Some observers have expressed opti-

159 See, eg, the profound uncertainty created in the UNFCCC Secretariat, prompting its Executive Secretary to issue a statement to UNFCCC staff: Patricia Espinosa Cantellano, 'Developments in the United States' (31 March 2017) <http://newsroom.unfccc.int/ unfccc-newsroom/developments-in-the-united-states-by-executive -secretary-patricia-espinosa> accessed 5 April 2017.

160 United States, 'US Nationally Determined Contribution' (3 September 2016) < http://www4.unfccc.int/ndcregistry/ PublishedDocuments/United $\% 20$ States $\% 20$ of $\% 20$ America $\% 20$ First/U.S.A. $\% 20$ First $\% 20$ NDC\%20Submission.pdf $>$ accessed 29 March 2017.

161 See Climate Action Tracker, 'USA' (25 January 2017) <http:// climateactiontracker.org/countries/usa.html > accessed 10 April 2017.

162 See, eg, David Victor, 'What a Trump Win Means For the Global Climate Fight' (YaleEnvironment360, 11 November 2016) <http:// e360.yale.edu/features/what_donald_trump_win_means_for global climate fight $>$ accessed 31 March 2017: 'With the withdrawal of U.S. support, efforts to implement the Paris agreement and avoid the most devastating consequences of global warming have suffered a huge blow.'

163 See Daniel Cusick, 'U.S. Void in Climate Pact Helps China be a "Superpower"' (ClimateWire, 10 March 2017) <https://www .eenews.net/climatewire/2017/03/10/stories/1060051270> accessed 29 March 2017; Zachary Shahan, 'India Commits To mism that the US will not surrender its leadership role on climate change, however, in which case it becomes particularly important for foreign partners to understand the domestic realities described in the previous sections and keep them separate from the political rhetoric dominating much of the current debate; in diplomatic relations, after all, perceptions do matter. ${ }^{166}$

\section{Outlook}

Following the recent election, a single party now holds the presidency and controls the $115^{\text {th }}$ Congress, having majorities in both the House of Representatives and the Senate. Republicans also hold a majority of governorships and state legislatures, affording them a concentration of power that will enable greater transformational change than in many prior decades. But Donald Trump, effectively the leader of the Republican Party, brings a brand of nationalist populism that sets him apart from recent presidencies. While climate policy has long been an issue that elicits open hostility among many conservatives, the new president and his cabinet have been described as a 'triumph of climate denial', ${ }^{167}$ dispensing with any remaining hesitation to oppose climate action and even the acknowledgment of climate science on political grounds. As the impacts of a warming at-
Continued Climate \& Cleantech Leadership In Spite Of Trump' (CleanTechnica, 19 January 2017) <https://cleantechnica.com/ 2017/01/19/india-commits-to-continued-cleantech-leadership-in -face-of-trump-video/> accessed 29 March 2017.

164 Michael Mehling, Kati Kulovesi and Javier de Cendra de Larragán, 'Climate Law and Policy in the European Union: Accidental Success or Deliberate Leadership?' in Erkki J Hollo, Kati Kulovesi and Michael Mehling (eds), Climate Change and the Law (Springer 2013), 509-520.

165 David Victor, 'Trump: China Could Take Lead on Climate' (2016) 539 Nature 495.

166 For instance, Michael J Bloomberg, the former Mayor of New York City and the UN Secretary-General's Special Envoy for Cities and Climate Change, declared that 'the United States can - and will - meet the commitment it made in Paris in 2015', adding that '[c]laims that the United States will no longer be able to meet its Paris obligations give other countries an excuse to walk away from theirs. How terrible it would be if a misunderstanding of American climate leadership - which is not based in Washington and never has been - led to an unraveling of the Paris Agreement', see Bloomberg ( $\mathrm{n} 68$ ).

167 Clare Foran, 'Donald Trump and the Triumph of Climate-Change Denial' (The Atlantic, 25 December 2016) <https://www theatlantic.com/politics/archive/2016/12/donald-trump-climate -change-skeptic-denial/51035> accessed 29 March 2017. 
mosphere become increasingly evident in the US ${ }^{168}$ and surveys show expanding concern about climate change, ${ }^{169}$ the underlying politics remain as partisan as ever. ${ }^{170}$

For the US response to climate change, one might expect this confluence of political power and unfettered partisanship to result in a terminal setback, but closer scrutiny shows that the outlook is likely more nuanced. A system of checks and balances and federal allocation of powers that dates back to well before anthropogenic climate change first became an issue may afford existing climate action surprising resilience against an ideological assault. Pending a legislative amendment or judicial determination that relieves the administration of its statutory obligation to regulate GHG emissions, for instance, the EPA will arguably find itself in a vulnerable position whenever it seeks to weaken or repeal existing executive rules, and could be forced to offer a reasoned argument why the growing body of scientific evidence on the reality and impacts of climate change nonetheless justifies scaling back action. Other federal agencies are bound by similar mandates, such as the DOT with its requirement to issue fuel economy standards under federal energy legislation. Challenging the legal basis in all cases would require overturning established case law of the Supreme Court or overcoming a filibuster with a supermajority in the Senate.

More likely, given the lengthy administrative process of notice and comment rulemaking and the likelihood of subsequent litigation, executive efforts to reverse climate regulation will merely have the effect of delaying progress, which translates into lost time for climate mitigation and adaptation, and a temporary reprieve for those opposing action. An inevitable companion of these delays is regulatory uncertainty, the natural antagonist of strategic investment decisions such as those required to achieve long-term decarbonisation of the economy. While less dramatic than outright reversal of climate action, delays and uncertainty represent a tangible - if not terminal - setback. Ironically, with the appointment of Neil M Gorsuch to the US Supreme Court, President Trump has installed an opponent of the Chevron doctrine of judicial deference to agency interpretations, ${ }^{171}$ increasing the likelihood of judicial scrutiny of his executive actions. Around the same time the Chevron doctrine was being formulated, Merrick B Garland, chief judge of the influential US Court of Appeals for the DC Circuit and President Obama's unsuccessful nominee for the same Supreme Court seat, helped define the standard of judicial review for rescission of agency regulations. ${ }^{172}$ Deregulation was on the agenda of the EPA, then headed by Gorsuch's mother, Anne M Gorsuch, who had overseen the largest budget cuts to date at her agency. Cognisant of how history can repeat itself, federal agencies in the Trump administration should beware of executive actions that might appear arbitrary or capricious, or that incur unreasonable delays in the fulfilment of statutory obligations.

Any federal lacunae left in the wake of regulatory reform are where subnational activism and the force of market fundamentals will be most apparent. States adopting ambitious mitigation targets or rapidly maturing markets for renewable energy technologies can each achieve far greater climate progress than fragmented agency regulations based on contested authorities, especially where these largely reflect fundamental trends that would have unfolded anyway. Unable to fully reverse even the disputed climate legacy of his predecessor, ${ }^{173}$ Donald Trump's deregulatory activism will likely be remembered more for its symbolic bluster and populist rhetoric than actual substantive achievements.

But measured against the level of policy ambition needed to achieve meaningful decarbonisation in North America, which would not only require strict enforcement of existing climate regulations, but also their rapid acceleration and expansion across all areas of the economy, it becomes clear that the delays, the policy uncertainty and the weakening or selective withdrawal of agency actions could be devastating precisely because they are so far removed from

168 Jerry M Melillo, Terese C Richmond and Gary W Yohe (eds), Climate Change Impacts in the United States: The Third National Climate Assessment (US Global Change Research Program 2014).

169 Anthony Leiserowitz et al, Climate Change in the American Mind: November 2016 (Yale Program on Climate Change Communication 2017); according to the survey results, Americans overwhelmingly believe that climate change is happening and that GHG emissions should be curbed, but fewer respondents are sure that a changing climate will harm them personally.

170 Riley E Dunlap, Aaron M McCright and Jerrod H Yarosh, 'The Political Divide on Climate Change: Partisan Polarization Widens in the U.S.' (2016) 58 Env: Sci Pol Sust Dev 4.

171 US Supreme Court, Chevron USA, Inc v Natural Resources Defense Council, Inc, 467 US 837 (S Ct 25 June 1984).

172 US Supreme Court (n 115).

173 David Bookbinder, 'The Obama Climate Legacy' (Niskanen Center, 11 April 2017) <https://niskanencenter.org/blog/ greenwashing-obama-climate-legacy/> accessed 12 April 2017. 
the required policy trajectory, a course even President Obama was unable to hold. ${ }^{174}$ Instead of building and improving on the legacy of his predecessor, Donald Trump seems bent on ensuring that future administrations will have to start their climate policy agenda from scratch. Of particular concern are the cuts to early stage research and development, an area which markets - for all their current success in increasing the uptake of renewable energy and other sustainable technologies - do not typically allocate sufficient resources to.

When considering the inordinate amount of time, effort and resources invested in elaborating some of the regulations and orders that are now being challenged, the scale of this setback becomes evident. Some changes, moreover, such as the passage of disapproval resolutions based on the CRA or severely curtailed agency budgets and staff capacities, ${ }^{175}$ will have a lasting impact beyond the current administration and constrain the ability of more progressive successors to rebuild a robust climate policy framework.

When it comes to US participation in international climate cooperation, care must be taken to distinguish political rhetoric at the federal level from fundamental drivers and the formidable impact of subnational actors, especially when these are energized by a perceived leadership vacuum in the national capital. America's Madisonian model of government ensures that climate progress will continue, even if it is less visible and more heterogeneous than it was during the last administration. Still, the power to define foreign policy rests with the executive branch, and that comes with numerous opportunities for obstruc- tion, as exemplified by early tensions in a Ministerial Meetings of the Group of Seven (G7). ${ }^{176}$ Severely diminished contributions to international climate finance would have a measurable impact on the political dynamic in international climate negotiations, and a disengaged US may also have a chilling effect on the stocktaking and periodic review processes under the Paris Agreement. But to assume that the US will formally withdraw from the international climate regime is premature, despite the attendant campaign promises: not only is there disagreement about the benefits of such withdrawal within the innermost circle of presidential advisers, but even the unlikeliest candidates have come forward to advocate for continued engagement, such as coal sector executives. ${ }^{177}$ A meeting of senior advisers and cabinet officials scheduled for the second half of April will offer more guidance on administration policy regarding continued participation in the Paris Agreement. ${ }^{178}$

History can be a useful guide when trying to see beyond the uncertainty surrounding a new and, in this case, remarkably unpredictable administration. Periods of regulatory activism followed by a deregulation reflex are not new in the evolutionary arc of US environmental policy. Alternative energy and conservation policies during the Carter administration gave way to frenzied deregulation and severe EPA budget cuts under President Reagan; attempts to pass a national energy tax and foster international engagement during the Clinton presidency were succeeded by withdrawal from the Kyoto Protocol and a period of domestic and foreign climate inaction under George W. Bush. In the end, it may be that

\footnotetext{
174 For the required mitigation efforts to achieve deep decarbonisation by mid-century, see White House, 'United States Mid-Century Strategy for Deep Decarbonization' (17 November 2016) <http://unfccc.int/files/focus/long-term_strategies/application/pdf/ mid_century_strategy_report-final_red.pdf> accessed 29 March 2017; for a global perspective, see Johan Rockström et al, 'A Roadmap for Rapid Decarbonization' (2017) 355 Science 1269.

175 Of all the measures initiated or proposed by the administration of Donald Trump so far, the requested funding cuts set out in his budget blueprint may have the most far-reaching implications. Envisioned spending cutbacks at the EPA, for instance, would force it to eliminate at least 50 individual programs and nearly 4,000 full-time equivalents in 2018, according to an internal EPA document that describes policy decisions to adjust to the expected budget reductions, see David A Bloom, Acting Chief Financial Officer, EPA, 'Memorandum: FY 2018 President's Budget: Major Policy and Final Resource Decisions' (21 March 2017), on file with author. And while individual budget cuts may not be able to pass Congress and the stakeholder preferences and expectations constraining lawmakers, the overall agenda of radically reducing
}

the size of government is very much in line with proposals by the conservative mainstream, see, for instance, the detailed budget recommendations compiled by the Heritage Foundation, Blueprint for Balance: A Federal Budget for 2017 (Heritage Foundation 2016), which foreshadows the extreme cuts to energy, environmental, and climate programs in the 2018 Budget Blueprint, Executive Office (n 12).

176 Andrew Restuccia, 'Trump's Climate Demands Roil U.S. Allies' (Politico, 11 April 2017) <http://www.politico.com/story/2017/ 04/trump-fossil-fuels-g7-tension-237129> accessed 12 April 2017.

177 Justin Worland, 'The Paris Agreement on Climate Change Has Surprising New Supporters' (Time, 10 April 2017) <http://time .com/4731582/coal-companies-climate-change-paris -agreement/> accessed 12 April 2017.

178 Eric Wolff, Andrew Restuccia and Josh Dawsey, 'White House Showdown on Paris Deal Set for Next Week' (Politico, 14 April 2017) <http://www.politico.com/story/2017/04/paris-climate-pact -trump-white-house-237234> accessed 15 April 2017. 
President Obama's progressive stance towards climate action was as much an outlier from the historical norm as the more adversarial approach practised by his predecessor, and that President Trump is merely affirming a historical pattern as he once again shifts the dial to the other extreme. Should that be true, the only way to escape this perpetual cycle of

179 Roger Pielke Jr, 'Experts Respond to Trump's Climate Blitzkrieg' (Bulletin of the Atomic Scientists, 29 March 2017) <http:// thebulletin.org/experts-respond-trump $\% \mathrm{E} 2 \% 80 \% 99 \mathrm{~s}$-climate -blitzkrieg10648> accessed 31 March 2017: 'Can those interested in climate action remake the subject into a bipartisan issue climate policy support and opposition in the US may be to seek a more inclusive middle ground, reframing climate action so that it may once again enjoy bipartisan approval. ${ }^{179}$ And while that may moderate climate progress, it will ultimately be preferable to the disruption caused by extreme shifts after every transition of power. respectful of all Americans and their values-regardless of their political party, home state, or education? We'd better, because without broad public support climate policies are going nowhere. We should pay attention to Trump's propaganda, there are lessons for us all there.' 